\title{
MULTI-OBJECTIVE OPTIMIZATION OF POTATO VARIETIES AND EFFECTIVE WAYS TO IMPROVE POTATO (SOLANUM TUBEROSUM L.) TUBER QUALITY IN THE LOESS PLATEAU OF CHINA
}

\author{
WANG, X. K. ${ }^{*}-$ XIE, K. \\ College of Life Science, Yan'an University, Yan'an, Shaanxi 716000, PR China \\ ${ }^{*}$ Corresponding author \\ e-mail:wangxiukang@126.com \\ (Received 10 $0^{\text {th }}$ Sep 2021; accepted $28^{\text {th }}$ Oct 2021)
}

\begin{abstract}
Choosing varieties that are suitable for planting in different areas has become a key scientific issue. We used principal component analysis (PCA) to evaluate and select better varieties with relatively high potato tuber yield and quality in the Loess Plateau of China. We selected fifteen potato varieties that are mainly grown locally for the experiment. The potato variety significantly affected potato tuber yield, dry matter accumulation, starch content, protein content, reducing sugar, total soluble sugar, vitamin $\mathrm{C}$, and browning intensity. The soil nitrate $\mathrm{N}$ content in $0-20 \mathrm{~cm}$ was $17.8 \%$ and $28.6 \%$ higher than that in $20-40 \mathrm{~cm}$ and 40-60 cm, respectively. Potato tuber yield was significantly correlated with the soil water, soil ammonium N, soil alkali-hydrolyzable $\mathrm{N}$, and soil available phosphorus contents. The starch content of potato tubers was significantly correlated with soil $\mathrm{pH}$ value and soil electrical conductivity. The potato variety of Xiapoti had the relatively high potato tuber yield, dry mater accumulation, starch content, total soluble sugar, and protein content. Therefore, Xiapoti is recommended as an optimal potato variety in the Loess Plateau of China.

Keywords: soil water content, soil nitrate nitrogen, soil organic matter, protein content, total soluble sugar, browning intensity
\end{abstract}

\section{Introduction}

Potato (Solanum tuberosum L.), a food crop in the Solanaceae family, is the fourth largest staple crop after corn, rice and wheat. It can provide more carbohydrates, proteins, minerals and vitamins per unit land area and time than other potential food crops (Hameed et al., 2018). In addition to being edible, potatoes are used industrially for processed foods, alcohol, starch, animal feed and biofuel production. Short crop durations and extensive climate adaptation have contributed to the spread of the potato across different geographical boundaries from its South American origin. Worldwide, there are more than 4,500 varieties of potatoes (e.g., Fovorita, Kexin No. 15, Atlantic...) are grown in more than 100 countries (Seibt et al., 2012). In terms of nutrition, the potato is a complex source of nutrients (vitamins, carotenoids, antioxidant phenols, proteins, magnesium, etc.), as well as a number of antinutrients (mainly glycoalkaloids). Potato tubers contain $77 \%$ water, $20 \%$ carbohydrates, and less than $3 \%$ protein, dietary fiber, minerals, vitamins, and other compounds on average (Camire et al., 2009; Visvanathan et al., 2016; Zaheer and Akhtar, 2016). The global importance of the potato is indisputable, placing it in the fight against food shortages and poverty.

The selection of varieties suitable for planting in different regions has become a key scientific problem. In particular, screening potato varieties with high yield and resistance to disease is more difficult. Hongmei is a new potato variety developed in recent years, which is also a rich source of high value proteins, antioxidants, phenolic compounds, and 
important minerals such as $\mathrm{K}$ and $\mathrm{Zn}$ (Xu et al., 2018). Choi et al. (2016) comprehensively analyzed the contents of protein amino acids, non-protein amino acids, glucose, fructose, sucrose, phenols and flavonoids in different varieties of potato. The characteristics and genes of different varieties were determined by plant biomass, gene variation, amino acid profile analysis and gene expression analysis to optimize potato varieties (Tiwari et al., 2020). The potato varieties suitable for local cultivation were screened through the effect of single virus and mixed virus infection on the yield of twelve varieties (eight locally bred and four imported) (Mulabisana et al., 2019). Yamdeu Galani et al. (2017) selected the better potato varieties by studying the adaptability evaluation of the contents of vitamin $\mathrm{C}$, total phenol, phenolic acid and antioxidant capacity of different potato varieties to storage temperature. Studies have shown that Saturna and Alegria have higher starch content and lower sucrose content in tubers under limited nitrogen conditions, which makes them excellent breeding candidates (Van Dingenen et al., 2019). However, these studies were limited to the merits of specific potato qualities and subjective evaluations based on data.

As the farmers in some areas have been planting potato varieties for a long time, the potato varieties in this area are deteriorating more and more seriously, thus making the potato yield lower and quality worse. This is closely related to soil physical and chemical properties and soil fertility in different areas. Soil available potassium had a positive effect on potato tuber starch and reducing sugar contents, and a negative effect on soluble protein and browning intensity (Xing et al., 2020; Xing et al., 2022). Potato tuber quality can be improved by increasing the calcium content of tubers (Palta, 2010). Soil nitrogen content is the key nutrient to improve the cv 'Symphonia' growth, yield and tuber quality in the local growing conditions of Punjab province Pakistan on sandy loam soil (Ayyub et al., 2019). Potato tuber yield is closely related to soil organic matter, $\mathrm{K}$ and $\mathrm{P}$ content in the northeastern United States (Porter et al., 1999). The effects on protein content, total phenols and antioxidant activity of healthy tubers depend on the interaction between environmental factors and genotype in southern Chile (Ávila-Valdés et al., 2020). Low soil moisture content decreased tuber dry weight, sugar and protein content, but increased polyphenols content and antioxidant activity (Elhani et al., 2019).

In the potato growing areas of the Loess Plateau in China, 50.3\% of farmers overapply fertilizer, which not only increases the planting cost, but also poses a potential threat to the soil (Wang et al., 2020). Therefore, it is necessary to study the local soil nutrient status in order to identify the most effective fertilization strategy. There are few reports on the correlation between tuber quality and soil nutrients of different potato varieties in the Loess Plateau area. The comprehensive evaluation of tuber yield and quality of different potato varieties on the Loess Plateau and the coupling effect between tuber yield and quality and soil nutrients have important theoretical and practical significance for optimizing field management. The objective of this study was (1) to quantify the coupling relationship between tuber quality of different potato varieties and soil nutrients; (2) to find out an optimal potato variety of yield and quality is relatively high based on principal component analysis (PCA). 


$$
-745 \text { - }
$$

\section{Materials and methods}

\section{Site description}

The experiment was carried out in the potato test station in Yulin Modern Agricultural Science and Technology Demonstration Park of Shaanxi Province from April to September 2019 and 2020 . The experimental site is located at $109^{\circ} 45^{\prime} 30^{\prime \prime} \mathrm{E}, 38^{\circ} 22^{\prime} 37^{\prime \prime} \mathrm{N}$, with an altitude of $1100 \mathrm{~m}$. The annual precipitation is concentrated in June, July and August, with an average precipitation of $400 \mathrm{~mm}$, annual evaporation of $1900 \mathrm{~mm}$, annual total sunshine hours of $2900 \mathrm{~h}$, and annual temperature of $8.5^{\circ} \mathrm{C}$ on average. According to the USDA soil classification system, the experimental site soil is sandy. The average sand, silt and clay contents in the $0-60 \mathrm{~cm}$ soil profile were measured with a laser particle size analyzer (Dandong Haoyu Technology Co., Ltd), and the values were 80.2\%, 14.1\% and $5.7 \%$, respectively. Before the experiment, the soil $\mathrm{pH}$ value was 8.1 ; the soil bulk density of $0-60 \mathrm{~cm}$ surface layer was $1.38 \mathrm{~g} \mathrm{~cm}^{-3}$; the soil field capacity was $21.4 \%$; the soil ammonium nitrogen content was $5.8 \mathrm{mg} \mathrm{kg}^{-1}$, soil nitrate nitrogen content was $2.1 \mathrm{mg} \mathrm{kg}^{-1}$, soil available phosphorus content was $6.2 \mathrm{mg} \mathrm{kg}^{-1}$, and soil available potassium content was $67.4 \mathrm{mg} \mathrm{kg}^{-1}$.

\section{Experimental design}

The experiment consisted of 15 different potato varieties, which were 1463-115 (T1), Feiurita (T2), Shaza (T3), Yushu 3 (T4), Qingshu 17 (T5), Laokoupi (T6), He 14 (T7), Qingshu 9 (T8), Xingjing 2 (T9), Longshu 13 (T10), Zhongshu 3 (T11), Akeria (T12), Yushu 4 (T13), Xiapoti (T14) and Longshu 7 (T15). According to the local actual production experience, the lower limit of soil moisture was set at different growth stages, and the soil moisture content of $65 \%$ soil field capacity (SFC) at seedling stage, tuber formation stage (70\% SFC), tuber expansion stage (75\% SFC), starch accumulation stage $\left(65 \%\right.$ SFC) and maturity stage (65\% SFC). Fertilizer application amount $\left(\mathrm{N}_{-} \mathrm{P}_{2} \mathrm{O}_{5}-\mathrm{K}_{2} \mathrm{O}\right)$ according to the local field fertilization standard is $240-120-300 \mathrm{~kg} \mathrm{ha}^{-1}$. The plot length is $20 \mathrm{~m}$, the width is $3.6 \mathrm{~m}$, and the plot area is $72 \mathrm{~m}^{2}$. In this experiment, potatoes were planted by mechanically ridging, the width between ridges was $90 \mathrm{~cm}$, the sowing distance between two potato plants was $25 \mathrm{~cm}$, and the planting density was about 45000 plants ha-1.

Field potato drip irrigation uses ridge drip irrigation. Since the root system of potato is mainly distributed in $0-40 \mathrm{~cm}$, the average soil water content below the surface of the soil is selected as $40 \mathrm{~cm}$. When the soil water content is lower than the lower limit of irrigation, irrigation will be started until the soil water content reaches the field water capacity. The thin-walled maze drip irrigation pipe with diameter of $16 \mathrm{~mm}$ was used for irrigation. The spacing between the transmitters was 0.3 meters. Water meters and ball valves are used to control the amount of water in each plot.

The N, P and $\mathrm{K}$ fertilizers applied in the experiment were urea, ammonium dihydrogen phosphate and potassium nitrate. The proportion of five times fertilizer application was 0: 2: 5: 3: 0 in the whole growth stage (seedling stage; tuber formation stage; tuber expansion stage; starch accumulation stage; maturity stage). The water-soluble fertilizer was applied to the soil with drip irrigation, and the utilization coefficient of irrigation water was 0.95 .

Potatoes were sown on May 8 and harvested on September 28, 2019. During the growth, from phase 39 on the $\mathrm{BBCH}$ scale (complete crop cover), the potato plants were treated thrice, in 20- to 30-day intervals, with growth stage. 


$$
\text { - } 746 \text { - }
$$

\section{Measurements and calculations}

\section{Tuber yield and tuber quality}

Potato tuber samples were taken from September 26 to September 28 in 2019. At the time of harvest, the fresh tuber weight per plant $\left(\mathrm{g} \mathrm{plant}^{-1}\right)$ were determined by the plants harvested ( 5 plants) from the central rows of the plots. At the same time. The starch content was measured using iodine colorimetry (Wang et al., 2019). The soluble protein content was determined by coomassie bright blue method (Liu et al., 2017). The vitamin $\mathrm{C}$ content was measured by titration (Wang et al., 2019). The reducing sugar content was determined by 3, 5-2 nitrosalicylic acid colorimetric method (Gao et al., 2015).

\section{Soil physical and chemical properties}

Soil samples were taken from September 26 to September 28 in 2019. The soil nitrate-N content $(N=5)$ in the $60 \mathrm{~cm}$ profile was measured using a spectrophotometer (UV-VIS 8500, China) with sampling a depth interval of $20 \mathrm{~cm}$ (Wang et al., 2018). Soil organic matter content was determined by potassium dichromate volumetric method (external heating method) with five replications and with a sampling depth interval of $0 \mathrm{~cm}$ to $60 \mathrm{~cm}$. Soil available phosphorus was determined by molybdenum antimony antispectrophotometry method with $\mathrm{NaHCO}_{3}$ extraction. Soil available potassium was determined by flame photometry method with $\mathrm{NH}_{4} \mathrm{OAc}$ extraction.

\section{PCA of the potato yield and tuber quality}

Principal component analysis (PCA) is a general term for a technique that uses complex basic mathematical principles to convert some variables that may be relevant into a smaller number of variables called principal components. The process for the analysis is as follows:

(1) Select sample parameters.

$$
X=\left[\begin{array}{cccc}
X_{11} & X_{12} & \cdots & X_{1 p} \\
X_{21} & X_{22} & \cdots & X_{2 p} \\
\vdots & \vdots & & \vdots \\
X_{n 1} & X_{n 2} & \cdots & X_{n p}
\end{array}\right]
$$

where $n$ is the measured value of the sample number (i.e., the potato yield, tuber quality), and $p$ is the variable number.

(2) Sample parameters are converted to standardized values.

$$
\begin{gathered}
x_{i j}^{*}=\frac{x_{i j}-\bar{x}_{j}}{s_{j}} \quad i=1,2, \ldots, n ; j=1,2, \ldots, p \\
\overline{w h e r e ~}_{j}=\frac{1}{n} \sum_{i=1}^{n} x_{i j}, s_{j}^{2}=\frac{1}{n-1} \sum_{i=1}^{n}\left(x_{i j}-\bar{x}_{j}\right)^{2} \text {, and } n \text { is the measured value of the sample }
\end{gathered}
$$
number. 


$$
-747 \text { - }
$$

(3) Calculate correlation matrix.

$$
R=\left[\begin{array}{cccc}
r_{11} & r_{12} & \cdots & r_{1 p} \\
r_{21} & r_{22} & \cdots & r_{2 p} \\
\vdots & \vdots & & \vdots \\
r_{p 1} & r_{p 2} & \cdots & r_{p p}
\end{array}\right]
$$

where $r_{i j}$ is the correlation coefficient of the original variable, $r_{i j}=r_{j i}$, and $r_{i j}$ is given by the following equation:

$$
r_{i j}=\frac{\sum_{k=1}^{n}\left(x_{k i}-\bar{x}_{i}\right)\left(x_{k j}-\bar{x}_{j}\right)}{\sqrt{\sum_{k=1}^{n}\left(x_{k i}-\bar{X}_{i}\right)^{2} \sum_{k=1}^{n}\left(x_{k j}-\bar{x}_{j}\right)^{2}}}
$$

(4) The eigenvalues of $R$ and eigenvectors of each sample number are calculated.

$$
|\lambda E-R|=0
$$

where $\lambda$ is the eigenvalue, $E$ is the identity matrix and $R$ is the correlation matrix. Next, these eigenvalues are sized down as $\lambda_{1} \geq \lambda_{2} \geq \cdots \geq \lambda_{p} \geq 0$, and the respective eigenvector $e_{i}(i=1,2, \cdots \cdots)$ solved for: $\left\|e_{i}\right\|=1$

where $e_{i j}$ is the $j$-th component of $e_{i} . \quad \sum_{j=1}^{p} e_{i j}^{2}=1$

(5) The characteristic values were used ${ }^{j=1}$ to calculate the contribution rate $\left(C_{r}\right)$ and accumulative contribution rate $\left(A C_{r}\right)$.

$$
\begin{gathered}
C_{r}=\frac{\lambda_{i}}{\sum_{k=1}^{p} \lambda_{k}}(i=1,2, \cdots, p) \\
A C_{r}=\frac{\sum_{k=1}^{i} \lambda_{k}}{\sum_{k=1}^{p} \lambda_{k}} \quad(i=1,2, \cdots, p)
\end{gathered}
$$

(6) The mathematical model is established based on the PCA, as defined in the following equation: 


$$
\begin{gathered}
Q_{1}=S_{11} X_{1}+S_{12} X_{2}+\cdots+S_{1 p} X_{p} \\
Q_{2}=S_{21} X_{1}+S_{22} X_{2}+\cdots+S_{2 p} X_{p} \\
\cdots \ldots \\
Q_{t}=S_{t 1} X_{1}+S_{t 2} X_{2}+\cdots+S_{t p} X_{p}
\end{gathered}
$$

where $S_{1 i}, S_{2 i}, \cdots, S_{t i}(i=1,2, \cdots, t)$ are the eigenvectors corresponding to the principal components, and $X_{1}, X_{2}, \cdots, X_{p}$ are the standardized values, the value of which is converted based on the sample parameters.

(7) The evaluation process is determined according to the comprehensive evaluation index $(Q)$.

$$
Q=\lambda_{1} Q_{1}+\lambda_{2} Q_{2}+\cdots+\lambda_{t} Q_{t}
$$

where $\lambda_{1}, \lambda_{2} \cdots \lambda_{t}$ are the characteristic values corresponding to the principal components, and $Q_{1}, Q_{2}, \cdots, Q_{t}$ are the evaluation values of the different irrigation and fertilization treatments. The advantages and disadvantages of treatment are positively correlated with the comprehensive evaluation indexes.

\section{Data analysis}

Analysis of variance was conducted to evaluate the effect of different potato varieties on tuber yield and quality. Significant differences between the detected parameters were compared by Tukey's HSD test at One-way ANOVA the 95\% confidence level ( $\mathrm{p}<0.05)$. In addition, the effect of different potato varieties on the relationships among all the parameters was calculated using bivariate correlations analysis (Correlation coefficients, Pearson; Test of Significance, Two-tailed). SPSS statistical software 16.0 and Sigma Plot 14.0 were used for statistical analysis and data plotting.

\section{Results}

\section{Potato tuber yield and quality}

Significant differences in potato tuber yield, dry matter accumulation, starch content, and protein content were observed in different potato varieties (Fig. 1). The high potato tuber yield was observed in T2 (1.45 kg plant $\left.{ }^{-1}\right)$, which was $20 \%$ to $71.7 \%$ higher than that in other potato varieties (Fig. 1A). The average tuber yield of each treatment in order from high to low in the top three was: T2 > T5 > T7 (Fig. 1A).

The high dry matter accumulation was observed in T14 (1.24 kg plant $\left.{ }^{-1}\right)$, which was $1.4 \%, 11.3 \%$, and $24.4 \%$ higher than that in T2, T5, and T7, respectively (Fig. 1B). The high starch content was observed in T4 (11.6\%), which was $1.6 \%$ to $39.9 \%$ higher than that in other potato varieties (Fig. 1C). The starch content in T4 was 3.9\%, 7.2\%, and $25.1 \%$ higher than that in $\mathrm{T} 2, \mathrm{~T} 5$, and $\mathrm{T} 7$, respectively (Fig. 1C). The high protein content 
was observed in $\mathrm{T} 15$, which was $47.7 \%, 48.1 \%$, and $64 \%$ higher than that in $\mathrm{T} 2$, $\mathrm{T} 5$, and T7, respectively (Fig. 1D).
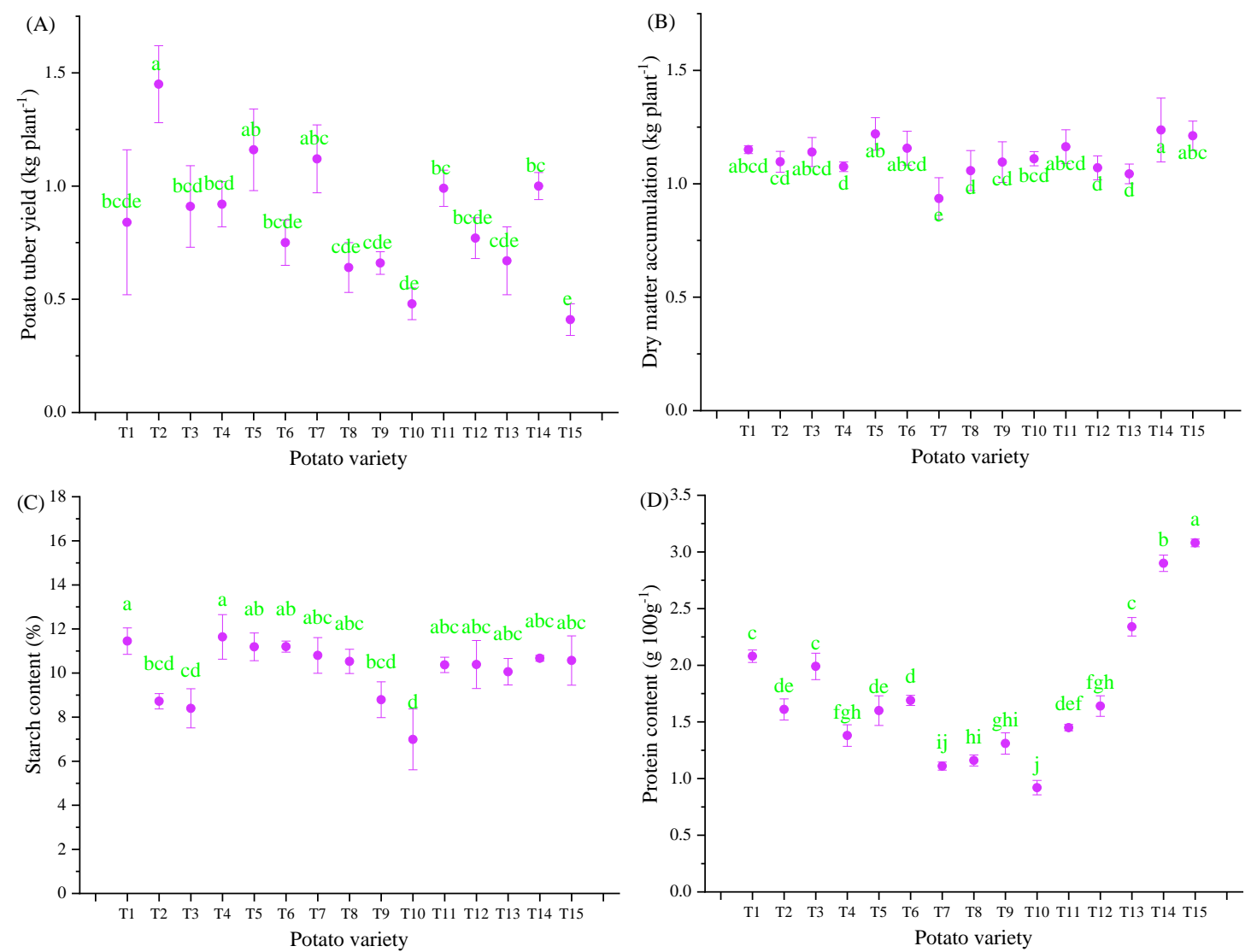

Figure 1. Effects of different potato varieties on potato tuber yield (A), dry matter accumulation (B), Starch content (C), and protein content (D). Note: T1, 1463-115; T2, Feiurita; T3, Shaza; T4, Yushu 3; T5, Qingshu 17; T6, Laokoupi; T7, He 14; T8, Qingshu 9; T9, Xingjing 2; T10, Longshu 13; T11, Zhongshu 3; T12, Akeria; T13, Yushu 4; T14, Xiapoti; T15, Longshu 7. Different lowercase letters indicate significant difference between treatments by the Tukey HSD test $(p<0.05)$

The potato variety significantly affected potato reducing sugar, total soluble sugar, vitamin $\mathrm{C}$, and browning intensity (Fig. 2). The high potato reducing sugar was observed in T3, which was $6.8 \%$ to $70.5 \%$ higher than that in other potato varieties (Fig. 2A). The average reducing sugar of each treatment in order from high to low in the top three was: T3 > T13 > T7 (Fig. 2A). The high total soluble sugar was observed in T13 (3.4\%), which was $20.8 \%$ to $63.5 \%$ higher than that in other potato varieties (Fig. $2 B$ ). The average total soluble sugar of each treatment in order from high to low in the top three was: T13 > T1 > T9 (Fig. 2B). The high vitamin $\mathrm{C}$ was observed in $\mathrm{T} 1$, which was $17.3 \%, 25.3 \%$, and $27.6 \%$ higher than that in T2, T5, and T7, respectively (Fig. 2C). The high browning intensity was observed in T11, which was $23.8 \%$ to $70.1 \%$ higher than that in other potato varieties (Fig. 2D). The browning intensity in T11 was $61.6 \%$ and $25.1 \%$ higher than that in $\mathrm{T} 2$ and $\mathrm{T} 5$, respectively (Fig. 2D). 

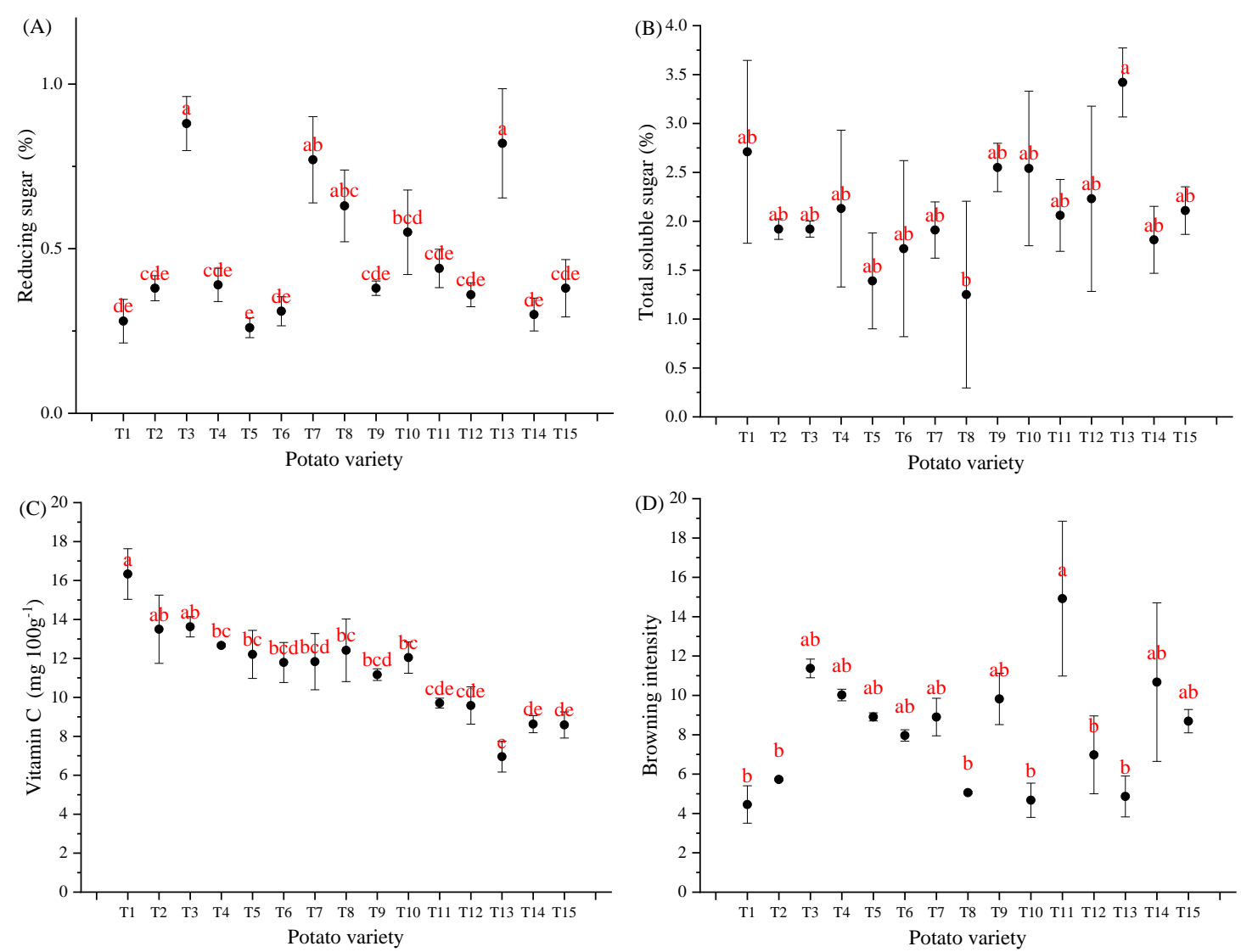

Figure 2. Effects of different potato varieties on reducing sugar (A), total soluble sugar (B), vitamin C (C), and browning intensity (D). Note: T1, 1463-115; T2, Feiurita; T3, Shaza; T4, Yushu 3; T5, Qingshu 17; T6, Laokoupi; T7, He 14; T8, Qingshu 9; T9, Xingjing 2; T10,

Longshu 13; T11, Zhongshu 3; T12, Akeria; T13, Yushu 4; T14, Xiapoti; T15, Longshu 7. Different lowercase letters indicate significant difference between treatments by the Tukey HSD test $(p<0.05)$

\section{Soil physical and chemical properties}

Significant differences in different soil depths of soil water content, $\mathrm{pH}$, and soil electric conductivity were observed in different potato varieties (Fig. 3). On average potato varieties, the soil water content decreased with the increase of soil depth, and the soil water content in $0-20 \mathrm{~cm}$ was $30.2 \%$ and $35.7 \%$ higher than that in $20-40 \mathrm{~cm}$ and 40-60 cm, respectively (Fig. 3A, D, G). On average soil depth, the high soil water content was observed in T11 (13\%), which was $17.3 \%, 25.3 \%$, and $27.6 \%$ higher than that in $\mathrm{T} 2$, T5, and T7, respectively (Fig. 3A, D, G). On average soil depth, the high pH was observed in T7, which was $1.9 \%$ to $8.3 \%$ higher than that in other potato varieties (Fig. 3B, E, H). The soil $\mathrm{pH}$ on average soil depth of each treatment in order from high to low in the top three was: T7 > T14 > T12 (Fig. 3B, E, H). On average potato varieties, the soil electric conductivity increased with the increase of soil depth, and the soil electric conductivity in $0-20 \mathrm{~cm}$ was $6.5 \%$ and $27.5 \%$ lower than that in $20-40 \mathrm{~cm}$ and $40-60 \mathrm{~cm}$, respectively (Fig. 3C, F, I). On average soil depth, the high electric conductivity was observed in T5, which was $8.3 \%$ to $44.1 \%$ higher than that in other potato varieties (Fig. 3C, F, I). 

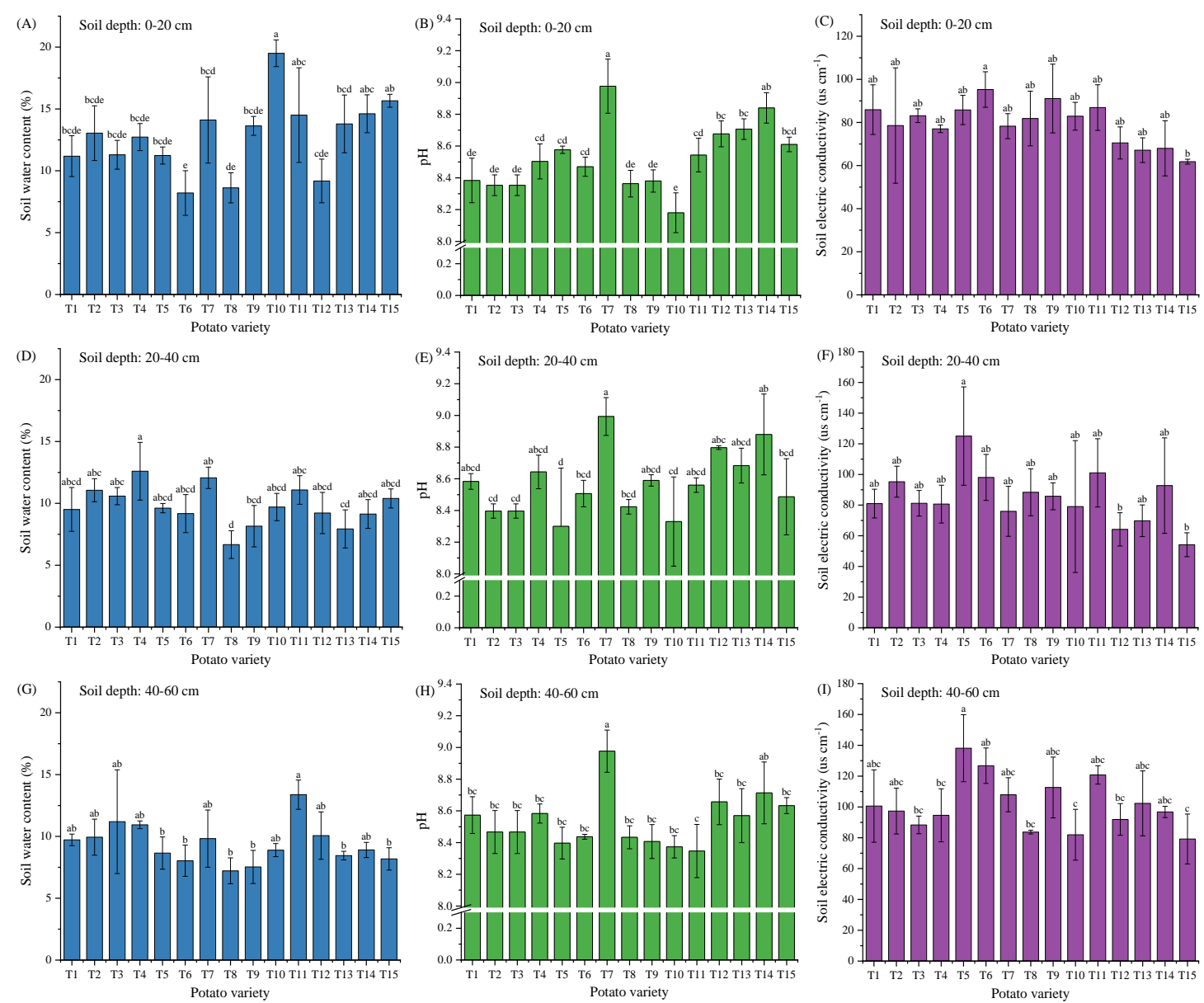

Figure 3. Effects of different potato varieties on soil water content $(A, D, G), p H(B, E, H)$, and soil electric conductivity $(C, F, I)$ in different soil depths $(0-20 \mathrm{~cm}, A, B, C ; 20-40 \mathrm{~cm}, D, E, F$; 40- 60 cm, G, H, I). Note: T1, 1463-115; T2, Feiurita; T3, Shaza; T4, Yushu 3; T5, Qingshu 17; T6, Laokoupi; T7, He 14; T8, Qingshu 9; T9, Xingjing 2; T10, Longshu 13; T11, Zhongshu 3; T12, Akeria; T13, Yushu 4; T14, Xiapoti; T15, Longshu 7. Different lowercase letters indicate significant difference between treatments by the Tukey HSD test $(p<0.05)$

The potato variety significantly affected soil nitrate $\mathrm{N}$, ammonium $\mathrm{N}$ and alkalihydrolyzed $\mathrm{N}$ contents (Fig. 4). On average potato varieties, the soil nitrate $\mathrm{N}$ content decreased with the increase of soil depth, and the soil nitrate $\mathrm{N}$ content in $0-20 \mathrm{~cm}$ was $17.8 \%$ and $28.6 \%$ higher than that in $20-40 \mathrm{~cm}$ and $40-60 \mathrm{~cm}$, respectively (Fig. $4 A, D$, $G)$. On average soil depth, the high soil nitrate $\mathrm{N}$ content was observed in T11, which was $20.4 \%$ to $74 \%$ higher than that in other potato varieties (Fig. 4A, D, G). On average soil depth, the highest soil ammonium $\mathrm{N}$ content was observed in $\mathrm{T} 11\left(10.2 \mathrm{mg} \mathrm{kg}^{-1}\right)$, which was $21.1 \%, 32 \%$, and $30.3 \%$ higher than that in T2, T5, and T7, respectively (Fig. 4B, E, $H$ ). On average potato varieties, the soil alkali-hydrolyzed $\mathrm{N}$ content decreased with the increase of soil depth, and the soil alkali-hydrolyzed N content in $0-20 \mathrm{~cm}$ was $6 \%$ and $18.3 \%$ higher than that in $20-40 \mathrm{~cm}$ and $40-60 \mathrm{~cm}$, respectively (Fig. $4 C, F, I$ ). On average soil depth, the high soil alkali-hydrolyzed $\mathrm{N}$ content was observed in $\mathrm{T} 2$, which was $3.5 \%$ to $42.3 \%$ higher than that in other potato varieties (Fig. $4 C, F, I$ ). 

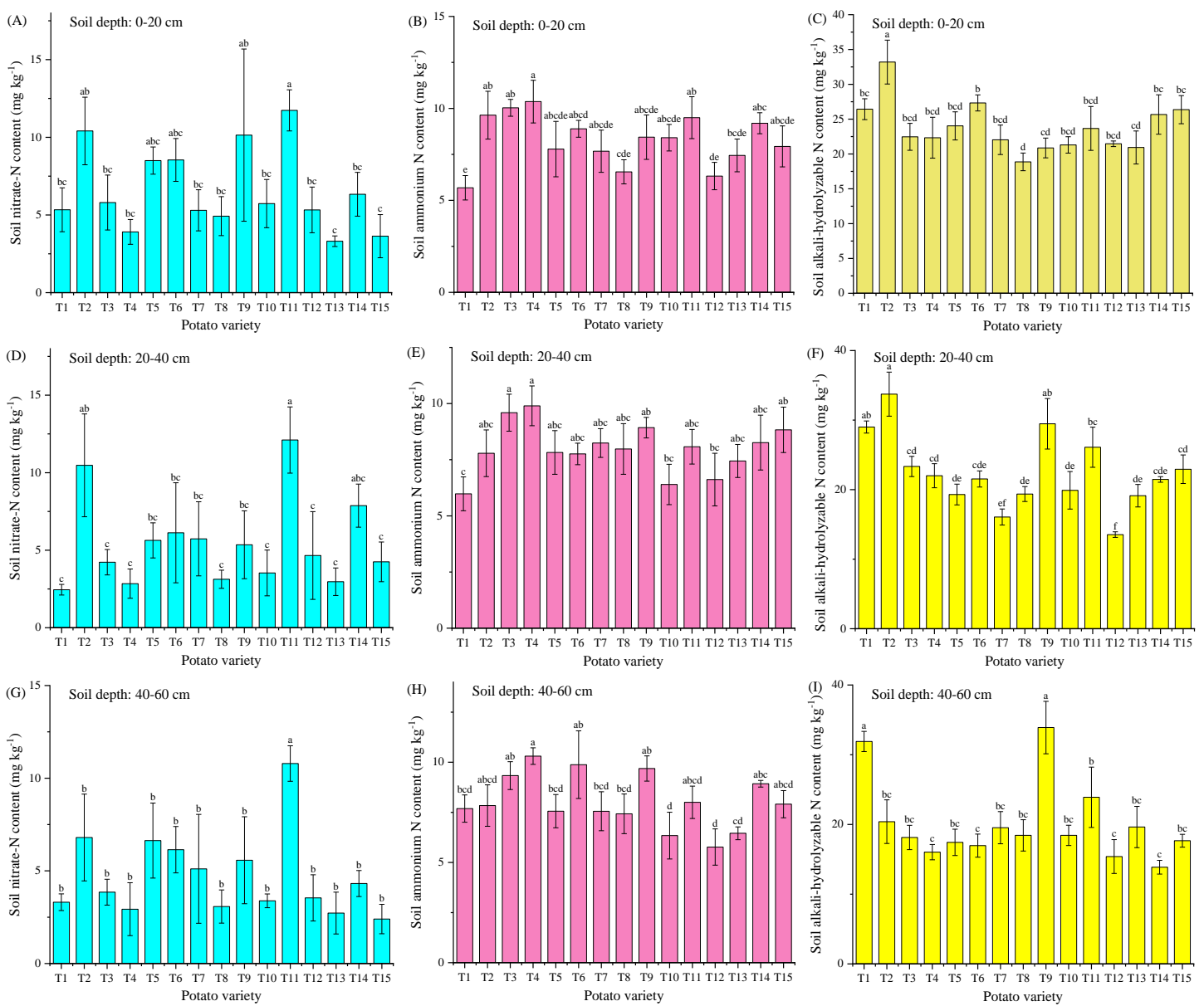

Figure 4. Effects of different potato varieties on soil nitrate- $N$ content $(A, D, G)$, soil ammonium $N$ content $(B, E, H)$, and soil alkali-hydrolyzable $N$ content $(C, F, I)$ in different soil depths $(0$ $20 \mathrm{~cm}, A, B, C$; $20-40 \mathrm{~cm}, D, E, F ; 40-60 \mathrm{~cm}, \mathrm{G}, \mathrm{H}, \mathrm{I}$ ). Note: T1, 1463-115; T2, Feiurita; T3, Shaza; T4, Yushu 3; T5, Qingshu 17; T6, Laokoupi; T7, He 14; T8, Qingshu 9; T9, Xingjing 2; T10, Longshu 13; T11, Zhongshu 3; T12, Akeria; T13, Yushu 4; T14, Xiapoti; T15, Longshu 7. Different lowercase letters indicate significant difference between treatments by the Tukey HSD test $(p<0.05)$

The potato variety significantly affected soil organic matter content, soil available phosphorus content, and soil available potassium content (Fig. 5). On average potato varieties, the soil organic matter content decreased with the increase of soil depth, and the soil organic matter content in $0-20 \mathrm{~cm}$ was $4.4 \%$ and $16.7 \%$ higher than that in $20-40 \mathrm{~cm}$ and 40-60 cm, respectively (Fig. 5A, D, G). On average soil depth, the high soil organic matter content was observed in T11, which was $6.2 \%$ to $50.7 \%$ higher than that in other potato varieties (Fig. 5A, D, G). On average potato varieties, the soil available phosphorus content decreased with the increase of soil depth, and the soil available phosphorus content in $0-20 \mathrm{~cm}$ was $25.2 \%$ and $28.3 \%$ higher than that in $20-40 \mathrm{~cm}$ and $40-60 \mathrm{~cm}$, respectively (Fig. 5B, E, H). On average soil depth, the high soil available phosphorus content was observed in T12, which was 34\%, 33.9\%, and 45.2\% higher than that in T2, T5, and T7, respectively (Fig. 5B, E, H). On average soil depth, the high soil available potassium content was observed in $\mathrm{T} 2$, which was $22.4 \%$ to $90.7 \%$ higher than that in 
other potato varieties, and the soil available potassium content in order from high to low in the top three was: T2 > T14 > T5 (Fig. 5C, F, I).
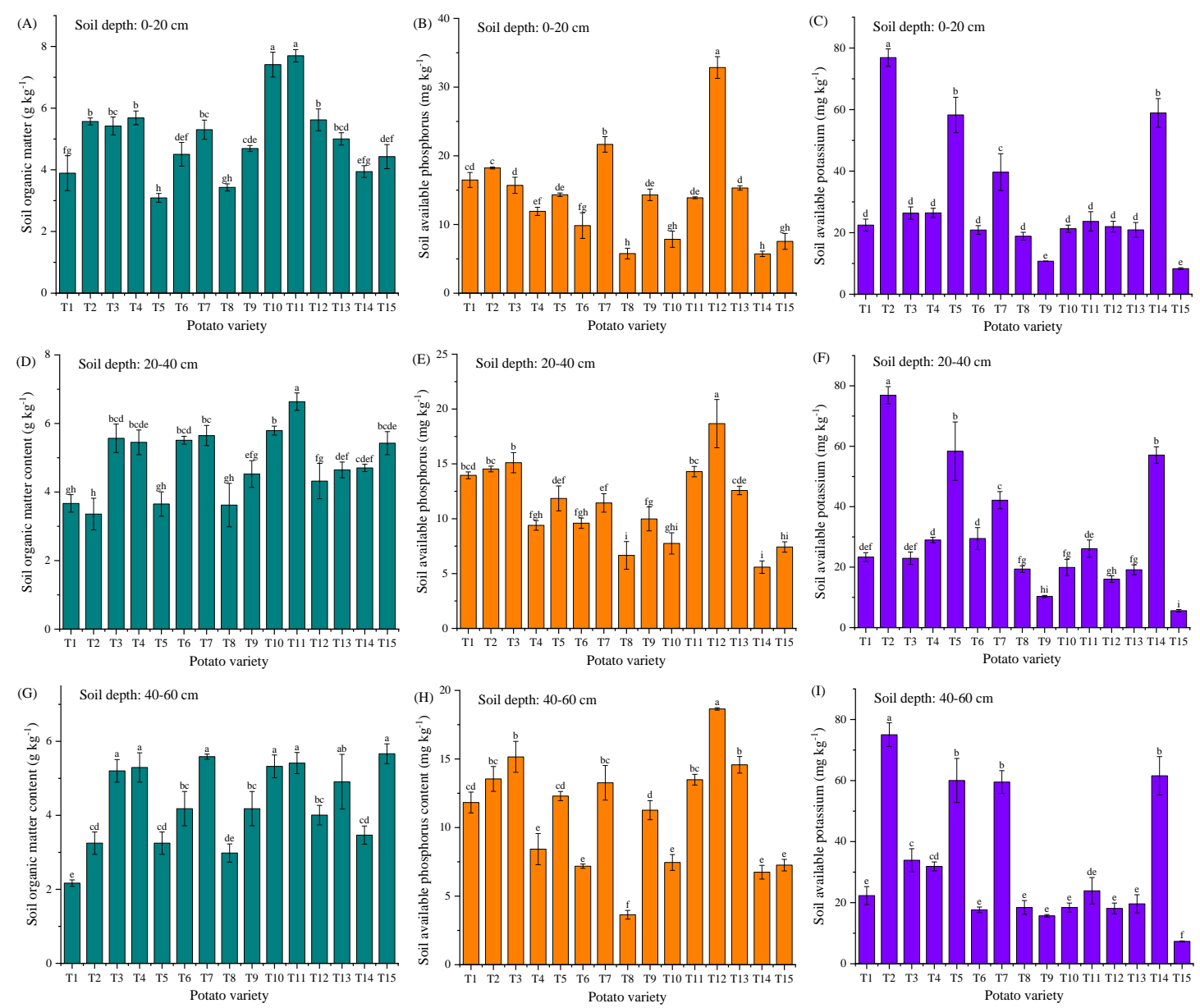

Figure 5. Effects of different potato varieties on soil organic matter content $(A, D, G)$, soil available phosphorus content $(B, E, H)$, and soil available potassium content $(C, F, I)$ in different soil depths (0-20 cm, A, B, C; 20- $40 \mathrm{~cm}, D, E, F ; 40-60 \mathrm{~cm}, \mathrm{G}, \mathrm{H}, \mathrm{I})$. Note: T1, 1463 115; T2, Feiurita; T3, Shaza; T4, Yushu 3; T5, Qingshu 17; T6, Laokoupi; T7, He 14; T8, Qingshu 9; T9, Xingjing 2; T10, Longshu 13; T11, Zhongshu 3; T12, Akeria; T13, Yushu 4; T14, Xiapoti; T15, Longshu 7. Different lowercase letters indicate significant difference between treatments by the Tukey HSD test $(p<0.05)$

\section{Correlation analysis and principal component analysis}

There were very significant $(\mathrm{p}<0.01)$ correlations between potato tuber yield and soil electric conductivity $\left(\mathrm{R}^{2}=0.3062\right)$, soil nitrate- $\mathrm{N}$ content $\left(\mathrm{R}^{2}=0.3178\right)$, soil available potassium $\left(\mathrm{R}^{2}=0.5433\right.$ ) (Table 1, Fig. 6). In addition, the potato tuber yield was significant $(\mathrm{p}<0.05)$ correlated with the soil water content $\left(\mathrm{R}^{2}=0.1181\right)$, soil ammonium $\mathrm{N}$ content $\left(\mathrm{R}^{2}=0.1024\right)$, soil alkali-hydrolyzable $\mathrm{N}$ content $\left(\mathrm{R}^{2}=0.093\right)$, and soil available phosphorus $\left(\mathrm{R}^{2}=0.1065\right)$ (Table 1, Fig. 6). The potato tuber starch content was very significant $(\mathrm{p}<0.01)$ correlated with the soil $\mathrm{pH}\left(\mathrm{R}^{2}=0.2107\right)$ and soil electric conductivity $\left(\mathrm{R}^{2}=0.1494\right)$ (Table 1, Fig. 6). 
Table 1. The correlation among the potato tuber yield, tuber quality, soil physical and chemical index using the average values $(n=3)$

\begin{tabular}{|c|c|c|c|c|c|c|c|c|c|c|c|c|c|c|c|c|c|}
\hline Item & TY & DMA & SC & PC & RS & TSS & VC & BI & SWC & pH & SEC & SNNC & SANC & SHNC & SOM & $\mathbf{P}$ & K \\
\hline TY & 1 & & & & & & & & & & & & & & & & \\
\hline DMA & 0.19 & 1 & & & & & & & & & & & & & & & \\
\hline SC & $.380 *$ & $.301 *$ & 1 & & & & & & & & & & & & & & \\
\hline PC & -0.026 & $.520 * *$ & 0.286 & 1 & & & & & & & & & & & & & \\
\hline $\mathbf{R S}$ & 0.146 & -0.171 & 0.036 & -0.066 & 1 & & & & & & & & & & & & \\
\hline TSS & 0.219 & 0.209 & $.315^{*}$ & 0.173 & $.398 * *$ & 1 & & & & & & & & & & & \\
\hline VC & $.453 * *$ & 0.18 & 0.206 & -0.232 & 0.116 & 0.215 & 1 & & & & & & & & & & \\
\hline BI & 0.285 & $.386 * *$ & 0.225 & 0.135 & 0.085 & 0.073 & -0.068 & 1 & & & & & & & & & \\
\hline SWC & $.344 *$ & 0.213 & 0.048 & 0.07 & 0.271 & $.376^{*}$ & 0.123 & $.430 * *$ & 1 & & & & & & & & \\
\hline pH & 0.241 & -0.157 & $.459 * *$ & 0.237 & 0.186 & 0.179 & -0.222 & 0.188 & 0.178 & 1 & & & & & & & \\
\hline SEC & $.553^{* *}$ & $.305^{*}$ & $.387 * *$ & -0.202 & -0.056 & 0.134 & $.398 * *$ & $.318^{*}$ & 0.048 & -0.102 & 1 & & & & & & \\
\hline SNNC & $.564 * *$ & $.319 *$ & 0.103 & -0.11 & -0.131 & 0.048 & 0.115 & $.483 * *$ & $.320 *$ & -0.074 & $.663^{* *}$ & 1 & & & & & \\
\hline SANC & $.320 *$ & 0.286 & 0.218 & 0.188 & 0.164 & 0.08 & 0.172 & $.603 * *$ & $.346^{*}$ & 0.014 & $.296^{*}$ & $.317 *$ & 1 & & & & \\
\hline SHNC & $.305^{*}$ & 0.271 & 0.029 & 0.161 & -0.186 & 0.255 & $.452 * *$ & 0.105 & 0.186 & -0.274 & $.316^{*}$ & $.476^{* *}$ & 0.212 & 1 & & & \\
\hline SOM & -0.097 & -0.114 & -0.195 & -0.165 & $.378^{*}$ & 0.2 & -0.203 & $.416^{* *}$ & $.678 * *$ & 0.075 & -0.116 & 0.186 & $.311^{*}$ & -0.158 & 1 & & \\
\hline $\mathbf{P}$ & $.326^{*}$ & -0.217 & 0.022 & -0.22 & 0.132 & 0.178 & 0.08 & 0.032 & 0.097 & 0.242 & 0.029 & 0.16 & -0.262 & 0.044 & 0.078 & 1 & \\
\hline $\mathbf{K}$ & $.737 * *$ & 0.107 & 0.054 & 0.006 & -0.125 & -0.172 & 0.188 & 0.075 & 0.175 & 0.174 & $.335^{*}$ & $.412 * *$ & 0.155 & 0.137 & -0.289 & 0.103 & 1 \\
\hline
\end{tabular}

Note: TY, potato tuber yield; DMA, dry matter accumulation; SC, Starch content; PC, protein content; RS, reducing sugar; TSS, total soluble sugar; VC, vitamin C; BI, browning intensity; SWC, soil water content; pH, soil pH; SEC, soil electric conductivity; SNNC, soil nitrate-N content; SANC, soil ammonium N content; SHNC, soil alkali-hydrolyzable $\mathrm{N}$ content. SOM, soil organic matter; $\mathrm{P}$, soil available phosphorus; $\mathrm{K}$, soil available potassium; **, Correlation is significant at the 0.01 level (2-tailed); *, Correlation is significant at the 0.05 level (2-tailed) 

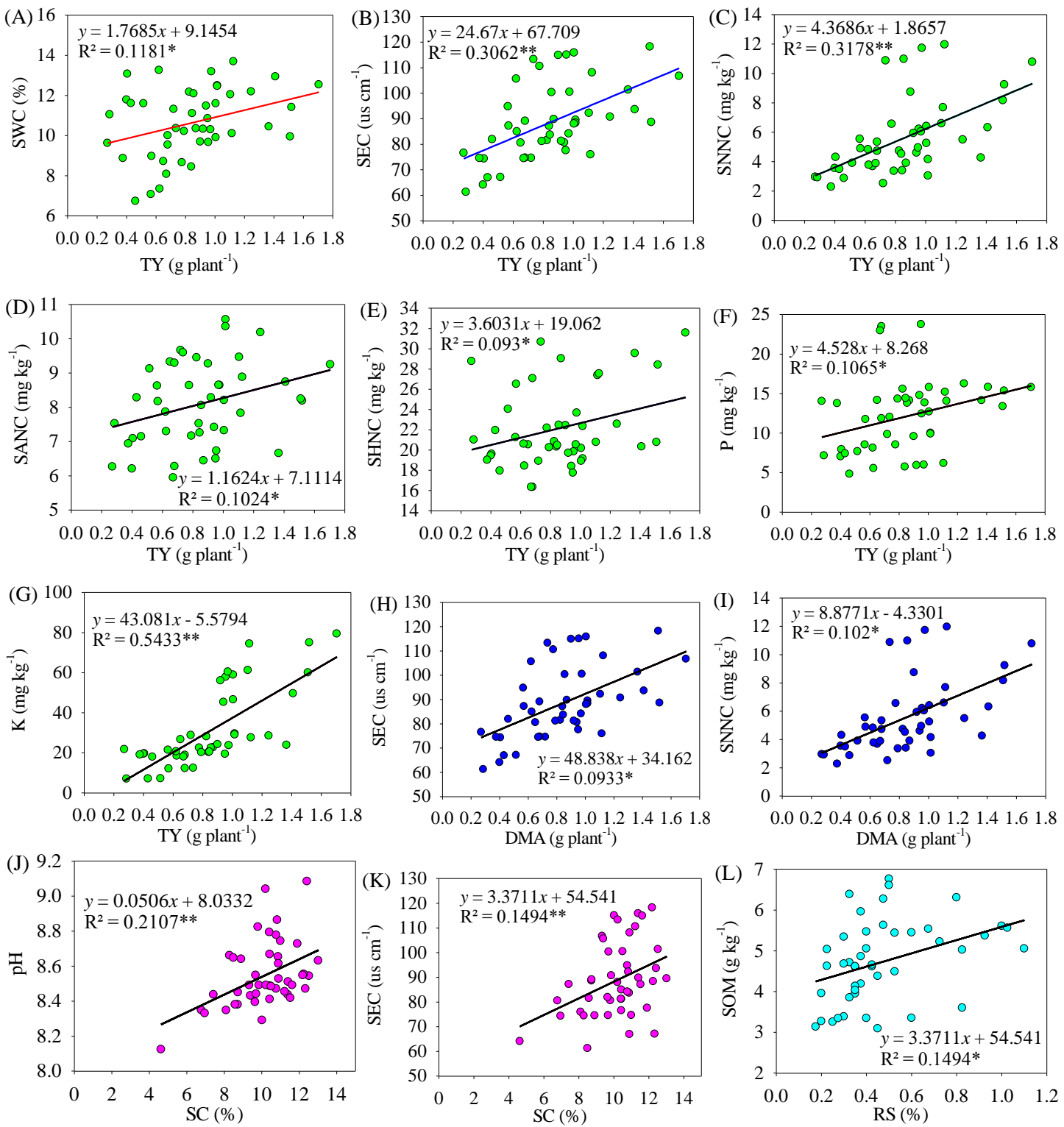

Figure 6. The linear relationship between soil index and potato tuber quality. Note: TY, potato tuber yield; DMA, dry matter accumulation; SC, Starch content; RS, reducing sugar; SWC, soil water content; $\mathrm{pH}$, soil $\mathrm{pH}$; SEC, soil electric conductivity; $S N N C$, soil nitrate- $N$ content; SANC, soil ammonium N content; SHNC, soil alkali-hydrolyzable N content; SOM, soil organic matter; $P$, soil available phosphorus; $K$, soil available potassium; **, Correlation is significant at the 0.01 level (2-tailed); *, Correlation is significant at the 0.05 level (2-tailed)

The vitamin $\mathrm{C}$ content was very significant $(\mathrm{p}<0.01)$ correlated with the soil electric conductivity $\left(\mathrm{R}^{2}=0.1587\right)$ and soil alkali-hydrolyzable $\mathrm{N}$ content $\left(\mathrm{R}^{2}=0.2039\right)$ (Table 1 , Fig. 7). The browning intensity was very significant $(\mathrm{p}<0.01)$ correlated with the soil water content $\left(\mathrm{R}^{2}=0.1846\right)$, soil nitrate- $\mathrm{N}$ content $\left(\mathrm{R}^{2}=0.2333\right)$, soil ammonium $\mathrm{N}$ content $\left(\mathrm{R}^{2}=0.3632\right)$, and soil organic matter $\left(\mathrm{R}^{2}=0.1729\right)($ Table 1, Fig. 7$)$. There was a significant linear relationship between potato tuber quality (Supplemental Fig. 1) and soil physical and chemical properties (Supplemental Fig. 2). 

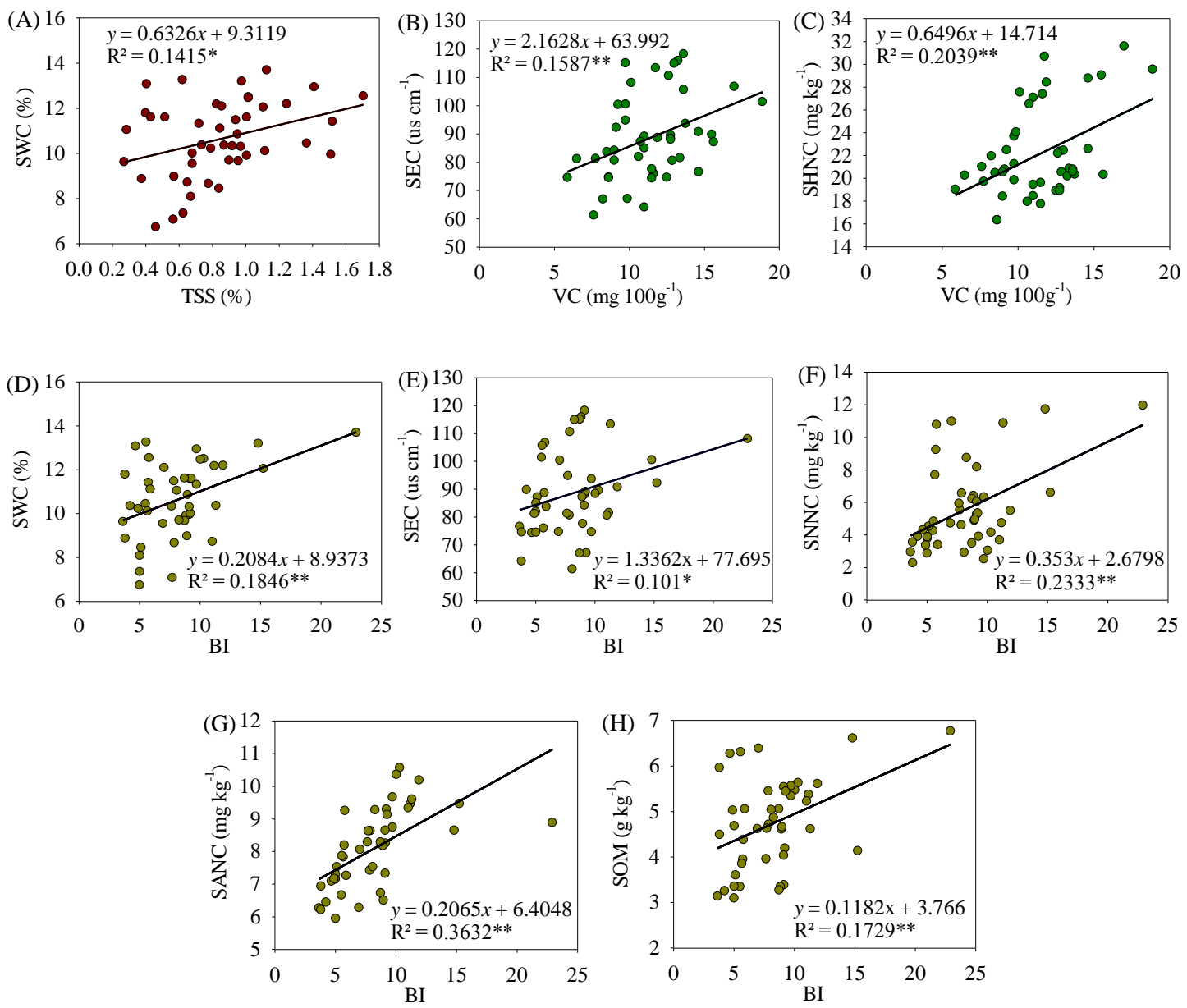

Figure 7. The linear relationship between soil index and potato tuber quality. Note: TSS, total soluble sugar; VC, vitamin C; BI, browning intensity; SWC, soil water content; SEC, soil electric conductivity; $S N N C$, soil nitrate- $N$ content; SANC, soil ammonium N content; SHNC, soil alkali-hydrolyzable N content; SOM, soil organic matter; **, Correlation is significant at the 0.01 level (2-tailed); *, Correlation is significant at the 0.05 level (2-tailed)

Based on all the collected data for the potato tuber yield, dry matter accumulation, Starch content, protein content, reducing sugar, total soluble sugar, vitamin $\mathrm{C}$, and browning intensity (Supplemental Table S1), it is theoretically possible to consider the standardized values as variables representing potato tuber quality (Supplemental Table S2). A correlation matrix was calculated from the standardized values (Supplemental Table S3). Then, the total variance explained by the $\mathrm{Cr}$ and the $\mathrm{ACr}$, based on eigenvalues was obtained by PCA (Supplemental Table S4). In this analysis, three components were extracted from the matrix of potato tuber quality parameters (Supplemental Table S5). Three component scores were also extracted from the matrix of fruit quality parameters (Supplemental Table S6). The comprehensive parameter rankings based on the PCA are shown in Table 2; T14 was ranked first, followed by T2 and T11, and T10 was clearly last. 


$$
\text { - } 757 \text { - }
$$

Table 2. The score and rank of the comprehensive potato tuber yield, dry matter accumulation, Starch content, protein content, reducing sugar, total soluble sugar, vitamin $C$, and browning intensity in a PCA of the potato varieties

\begin{tabular}{c|c|c|c|c|c}
\hline Treatments & Q1 & Q2 & Q3 & Q & Rank \\
\hline T1 & 1.121 & -0.759 & -1.961 & -0.147 & 10 \\
T2 & -0.183 & 0.793 & -1.100 & -0.024 & 8 \\
T3 & -0.984 & 0.602 & 0.785 & -0.022 & 7 \\
T4 & 0.040 & 0.665 & -0.242 & 0.134 & 6 \\
T5 & 1.151 & 1.208 & -0.377 & 0.559 & 2 \\
T6 & 0.809 & 0.186 & -0.390 & 0.217 & 5 \\
T7 & -1.781 & 1.115 & 0.140 & -0.221 & 12 \\
T8 & -0.581 & 0.247 & -0.841 & -0.229 & 13 \\
T9 & -0.399 & -0.390 & 0.047 & -0.199 & 11 \\
T10 & -0.993 & -1.304 & -0.981 & -0.735 & 15 \\
T11 & -0.009 & 1.149 & 1.479 & 0.485 & 3 \\
T12 & -0.002 & -0.405 & -0.048 & -0.104 & 9 \\
T13 & -1.031 & -2.057 & 1.070 & -0.626 & 14 \\
T14 & 1.480 & 0.203 & 1.310 & 0.659 & 1 \\
T15 & 1.362 & -1.254 & 1.111 & 0.250 & 4 \\
\hline
\end{tabular}

Note: T1, 1463-115; T2, Feiurita; T3, Shaza; T4, Yushu 3; T5, Qingshu 17; T6, Laokoupi; T7, He 14; T8, Qingshu 9; T9, Xingjing 2; T10, Longshu 13; T11, Zhongshu 3; T12, Akeria; T13, Yushu 4; T14, Xiapoti; T15, Longshu 7

\section{Discussion}

In sandy soils, potato tuber yields are often limited by water shortages and soil nutrient deficiencies. Therefore, more accurate farmland management technology is an effective way to increase potato yield (Wang et al., 2020). In this study, the potato tuber yield was more correlated to the soil available potassium $\left(R^{2}=0.5433\right)$ than to the soil water content $\left(\mathrm{R}^{2}=0.1181\right)$. The correlation order of potato tuber yield to soil nutrients was as follows: soil available potassium $>$ soil nitrate $\mathrm{N}$ content $>$ soil electric conductivity $>$ soil water content $>$ soil available phosphorus (Table 1). Studies have shown that the most important soil nutrient that affects potato yield is available potassium content (Panique et al., 1997; Koch et al., 2020). The critical level of soil exchangeable potassium at $90 \%$ relative yield was $105 \mathrm{mg} \mathrm{kg}^{-1}$ which can be a reference for potassium recommendation (Li et al., 2015). Fertilization recommendations should consider the balance between the input and output of soil potassium. Fertilizer potassium levels based on potassium removal rates depend on soil potassium levels and targets. In order to maintain the potassium content of the soil, the recommended amount of potassium in the fertilizer should be the same as that removed from the potato plant (Job et al., 2019). Because the soil potassium content in this study area is insufficient and the soil potassium resources are limited, it is suggested that the application amount of potassium fertilizer should be greater than the amount of potassium fertilizer removed to improve the soil potassium capacity. The amount of potassium application can not only meet the needs of crop, but also increase the soil potassium content, so that the soil potassium test value can be increased above the critical value. Therefore, the amount of potassium removed from the potato plant at the target yield can be calculated according to the relationship between the total potassium absorbed 
by the potato plant and the tuber yield. In order to determine the exact application rate, it is necessary to study the target potato tuber yield in this area.

This study showed that there was no significant correlation between soil $\mathrm{pH}$ and potato tuber yield. However, Jasim et al. (2020) reported that soil pH was significantly correlated with total potato tuber yield $\left(\mathrm{R}^{2}=0.38\right)$. The reason for this phenomenon may be that the acid soil has a significant effect on potato tuber yield, while the alkaline soil has no significant effect on potato tuber yield. We found for the first time that potato tuber starch content is strongly correlated with soil $\mathrm{pH}$ value and soil electrical conductivity. Soil $\mathrm{pH}$ value is the key factor affecting phosphorus availability in potato production (Visscher et al., 2020). The average soil $\mathrm{C}$ and $\mathrm{P}$ concentrations were significantly increased and the soil $\mathrm{pH}$ and $\mathrm{K}$ values were decreased under the tillage method with average mineral nitrogen fertilizer (Tein et al., 2014). This study showed that the potato tuber starch content increased with the increase of soil $\mathrm{pH}$ value. Potato planting has an effect on soil $\mathrm{pH}$, but the change is not enough to cause significant problems with $\mathrm{pH}$ between some of the agricultural systems seen after potato planting (Senbayram et al., 2015). The $\mathrm{pH}$ value in the organic system was significantly higher than that in the conventional system with average and heavy application of nitrogen fertilizer (Grandy et al., 2002). In this study, the change of soil $\mathrm{pH}$ was not a problem, but if this trend continues, the soil in the conventional system may become more alkaline.

This study showed that the potato tuber reducing sugar content was only significantly correlated with the soil organic matter content, and the reducing sugar content was increased with the increase of soil organic matter content. Zhang et al. (2020) reported that nitrogen application had significant effect on the concentration of potato tuber reducing sugar. However, this study shows that there is no significant negative correlation between soil nitrate $\mathrm{N}$ content and potato tuber reducing sugar content. This phenomenon indicates that potato varieties have more influence on the content of reducing sugar in tubers than soil fertility. The higher is the reducing sugars content, the darker is the colour of fried potatoes by effect of the Maillard reaction with aminoacids during frying (IlleraVives et al., 2017). The increase of reducing sugar may be due to the delay of maturation by excessive nitrogen application, which increases the content of dry matter and reducing sugar (Petropoulos et al., 2020). Most potato varieties in this study had more reducing sugars than the recommended level of potato chips $(<0.25 \%)$, which meet the recommended range for potato chips and flakes $(0.4-0.6 \%$ and $0.4-1 \%$, respectively).

The total soluble sugar of potato tuber was positively correlated with soil water content in this study. The potato tuber total soluble sugar was significantly affected by soil temperature and soil water content in a Duric Hapludand soil (Ávila-Valdés et al., 2020). The potato tuber total soluble sugar was significantly accumulated under drought stress, and the tuber total soluble was significantly decreased with the increase of age, with the result that the difference between different treatments was increased by $18.7 \%$ (Rudack et al., 2017). In this study, the total soluble sugar content of potato tubers increased with the increase of soil water content, and the increase rate was 0.63 . We found for the first time that a significant correlation between potato vitamin $\mathrm{C}$ content and soil electrical conductivity. In this study, the vitamin $C$ content of potato tubers increased with the increase of soil electrical conductivity. The internal mechanism of the effect of soil conductivity on the potato tuber vitamin $\mathrm{C}$ content needs to be further studied, which will be conducive to the further adjustment of soil conductivity to achieve the goal of improving vitamin $\mathrm{C}$ content. The potato tuber vitamin $\mathrm{C}$ content was greatly correlated to the soil alkali-hydrolyzable N content. Gao et al. (2015) showed that there was no 
significant difference in the contents of vitamin $\mathrm{C}$, soluble protein and starch in potato tubers under different $\mathrm{N}$ fertilization conditions. This is consistent with our research that there was no significant correlation between vitamin $\mathrm{C}$ content and soil nitrate $\mathrm{N}$ content.

The potato tuber browning intensity was significantly correlated with the contents of soil nitrate- $\mathrm{N}\left(\mathrm{R}^{2}=0.2333\right)$, soil ammonium $\mathrm{N}\left(\mathrm{R}^{2}=0.3632\right)$, and soil organic matter $\left(\mathrm{R}^{2}=0.1729\right)$ in this study. Browning reaction often occurs during the processing of fresh potato tuber, which leads to the decrease of the quality and nutritional value of processed products (Xing et al., 2020). Several researchers have shown that the relationship between soil nutrient supply and physiological processes has an important effect on potato tuber quality, such as potassium which has the greatest effect on potato tuber quality potato growth and photosynthesis (Naumann et al., 2020). The undesirable Browning of potato is the result of the joint action of potato chemical composition and enzyme activity. The Browning of fresh-cut potato is caused by the activation of enzymes when exposed to oxygen in the process of cutting potato. Phenolic compounds are converted to quinones, which in turn form melanin (Dite Hunjek et al., 2020). The susceptibility of many varieties to Browning has been studied. In several studies, the following varieties have been studied according to the browning sensitivity sequence: Monalisa > Spunta > Speech > Cara > Agria (Cantos et al., 2002) and Marabel > Agata > Agria > Vivaldi > Almera (Cabezas-Serrano et al., 2009). The potato tuber browning intensity in this study was ranked as: T11 (Zhongshu 3) > T3 (Shaza) > T14 (Xiapoti) > T4 (Yushu 3) > T9 (Xingjing 2). Besides potato variety, the enzymes activity could be helpful for browning decrease (Zhou et al., 2019). It can be inferred from the results of this study that the best measure to adjust the browning intensity is to increase the soil nitrate- $\mathrm{N}$, ammonium $\mathrm{N}$ and organic matter content.

Principal component analysis (PCA) is an unsupervised multivariate analysis used to transform a set. It converts the observed variables into a new set of unrelated variables and reduces the dimension by designing a new coordinate axis, called the principal component (de Mello et al., 2016). Many researchers suggest that PCA is used for data analysis when selecting the optimal parameter combination in various fields (Jolliffe Ian and Cadima, 2016; Tyanova et al., 2016; Li et al., 2018; Xing et al., 2021). Dersseh et al. (2016) explored that improved varieties, inorganic fertilizers, and strong marketing products are the best combination of potato farming systems in Chencha, Ethiopia by using PCA. Muthoni et al. (2015) used PCA method to select the best genotype and environmental factors suitable for the stability of potato tuber yield and resistance to bacterial wilt in Kenya. The first three principal components contributing about $89.9 \%$ in 2017 and $93.1 \%$ in 2018 of the variances with eigenvalues of $>1.0$ were employed to draw the distribution map of factor loading (Wang et al., 2020). Our study shows that the first three principal components contributing about $66.7 \%$ of the variances with eigenvalues of $>1.0$ were employed to draw the distribution map of factor loading.

Our study shows that T14 (Xiapoti) ranks the first through the PCA. The T14 treatment had the relatively high dry mater accumulation, starch content and total soluble sugar. Especially, the T14 treatment has relatively moderate potato tuber yield, protein content in this study. Therefore, T14 treatment is recommended to be as an optimal potato variety in sandy soil areas. This research method further clarifies the objectivity of selecting the optimal potato variety suitable for sandy soil, and explores the importance of field management in regulating potato tuber quality. 


$$
-760 \text { - }
$$

\section{Conclusion}

The potato variety significantly affected potato tuber yield and quality. The contents of soil nitrate $\mathrm{N}$, ammonium $\mathrm{N}$ and alkali-hydrolyzed $\mathrm{N}$ decreased with the increase of soil depth on average potato varieties. The soil nitrate $\mathrm{N}$ content in $0-20 \mathrm{~cm}$ was $17.8 \%$ and $28.6 \%$ higher than that in $20-40 \mathrm{~cm}$ and $40-60 \mathrm{~cm}$, respectively. The soil available potassium content in order from high to low in the top three was: T2 $>$ T14 > T5. Potato tuber yield was significantly correlated with the contents of soil water, soil ammonium N, soil alkali-hydrolyzable N, and soil available phosphorus. The starch content of potato tuber was significantly correlated with soil $\mathrm{pH}$ value and soil electrical conductivity. The content of vitamin $\mathrm{C}$ was significantly correlated with soil electrical conductivity and soil alkali-hydrolyzable nitrogen $\mathrm{N}$ content. The intensity of browning was significantly correlated with the contents of soil water, ammonium $\mathrm{N}$, alkali-hydrolyzed $\mathrm{N}$ and organic matter. The potato variety of Xiapoti (T14) had the relatively high dry mater accumulation, starch content and total soluble sugar. This method elucidates the contribution and impact of these measures and provides a basis for evaluating and selecting better potato varieties. These results are of great significance for improving field crop fertilizer input management in Northwest China and other regions of the world. In the future, we will focus on irrigation and fertilization levels, including more fractional levels, to better estimate the input of Xiapoti.

Acknowledgments. This research was supported by the National Natural Science Foundation of China (51809224) and Graduate Education Innovation Program of Yan'an University (YCX2021076).

\section{REFERENCES}

[1] Ávila-Valdés, A., Quinet, M., Lutts, S., Martínez, J. P., Lizana, X. C. (2020): Tuber yield and quality responses of potato to moderate temperature increase during tuber bulking under two water availability scenarios. - Field Crops Research 251: 107786.

[2] Ayyub, C. M., Muhammad, W. H., Faisal, Z., Zainul, A., Shawn, R. W. (2019): Potato tuber yield and quality in response to different nitrogen fertilizer application rates under two split doses in an irrigated sandy loam soil. - Journal of Plant Nutrition 42: 1850-60.

[3] Cabezas-Serrano, A. B., Amodio, M. L., Cornacchia, R., Rinaldi, R., Colelli, G. (2009): Suitability of five different potato cultivars (Solanum tuberosum L.) to be processed as fresh-cut products. - Postharvest Biology and Technology 53(3): 138-44.

[4] Camire, M. E., Stan, K., Danielle, J. D. (2009): Potatoes and Human Health. - Critical Reviews in Food Science and Nutrition 49: 823-40.

[5] Cantos, E., Tudela, J. A., Gil, M. I., Espín, J. C. (2002): Phenolic Compounds and Related Enzymes Are Not Rate-Limiting in Browning Development of Fresh-Cut Potatoes. Journal of Agricultural and Food Chemistry 50: 3015-23.

[6] Choi, S., Nobuyuki, K., Hyun-Jeong, K., Mendel, F. (2016): Analysis of protein amino acids, non-protein amino acids and metabolites, dietary protein, glucose, fructose, sucrose, phenolic, and flavonoid content and antioxidative properties of potato tubers, peels, and cortexes (Pulps). - Journal of Food Composition and Analysis 50: 77-87.

[7] de Mello, C. S., van Dijk, J. P., Voorhuijzen, M., Kok, E. J., Maisonnave Arisi, A. C. (2016): Tuber proteome comparison of five potato varieties by principal component analysis. Journal of the Science of Food and Agriculture 96: 3928-36.

[8] Dersseh, W. M., Yenenesh, T. G., Rogier, P. O. S., Paul, C. (2016): Struik. The analysis of potato farming systems in Chencha, Ethiopia: input, output and constraints. - American Journal of Potato Research 93: 436-47. 


$$
-761 \text { - }
$$

[9] Dite, H., Draženka, M. R., Mario, Š., Sven, K., Nada, V., Damir, J., Kata, G., Branka, L. (2020): Effect of anti-browning agents and package atmosphere on the quality and sensory of fresh-cut birgit and lady claire potato during storage at different temperatures. - Journal of Food Processing and Preservation 44: 14391.

[10] Elhani, S., Maroua, H., Csákvári, E., Hamim, A., Villányi, V., Douaik, A., Bánfalvi, Zs. (2019): Effects of partial root-zone drying and deficit irrigation on yield, irrigation wateruse efficiency and some potato (Solanum Tuberosum L.) quality traits under glasshouse conditions. - Agricultural Water Management 224: 105745.

[11] Gao, X., Li, C., Zhang, M., Wang, R., Chen B. (2015): Controlled release urea improved the nitrogen use efficiency, yield and quality of potato (Solanum Tuberosum L.) on silt loamy soil. - Field Crops Research 181: 60-68.

[12] Grandy, A. S., Porter, G. A., Erich, M. S. (2002): Organic amendment and rotation crop effects on the recovery of soil organic matter and aggregation in potato cropping systems. - Soil Science Society of America Journal 66(4): 1311-1319.

[13] Hameed, A., Syed, S. Z., Sara, S., Shahid, M. (2018): Applications of New Breeding Technologies for Potato Improvement. - Frontiers in Plant Science 9: 925.

[14] Illera-Vives, M., Labandeira, S. S., Loureiro, L. I., López-Mosquera, M. E. (2017): Agronomic assessment of a compost consisting of seaweed and fish waste as an organic fertilizer for organic potato crops. - Journal of Applied Phycology 29: 1663-71.

[15] Jasim, A., Sharma, L., Zaeen, A. A., Bali, S., Buzza, A., Alyokhin, A. (2020): Potato phosphorus response in soils with high value of phosphorus. - Agriculture 10(7): 264.

[16] Job, A. L. G., Soratto, R. P., Fernandes, A. M., Assuncao, N. S., Fernandes, F. M., Yagi, R. (2019): Potassium fertilization for fresh market potato production in tropical soils. Agronomy Journal 111: 63351-62.

[17] Jolliffe, I. T., Jorge, C. (2016): Principal Component Analysis: A review and recent developments. - Philosophical Transactions of the Royal Society A: Mathematical, Physical and Engineering Sciences 374: 20150202.

[18] Koch, M., Naumann, M., Pawelzik, E., Gransee, A., Thiel, H. (2020): The importance of nutrient management for potato production Part I: plant nutrition and yield. - Potato Research 63: 97-119.

[19] Li, S., Duan, Y., Guo, T., Zhang, P., He, P., Johnston, A., Shcherbakov, A. (2015): Potassium management in potato production in Northwest Region of China. - Field Crops Research 174: 48-54.

[20] Li, Y., Zhang, J., Wang, Y. (2018): Ft-Mir and Nir spectral data fusion: a synergetic strategy for the geographical traceability of panax notoginseng. - Analytical and Bioanalytical Chemistry 410: 91-103.

[21] Liu, Q., Guo, Q., Akbar, S., Zhi, Y., El Tahchy, A., Mitchell, M., Li, Z., Shrestha, P., Vanhercke, T., Ral, J. P., Liang, G., Wang, M. B., White, R., Larkin, P., Singh, S., Petrie, J. (2017): Genetic enhancement of oil content in potato tuber (Solanum Tuberosum L.) through an integrated metabolic engineering strategy. - Plant Biotechnology Journal 15(1): 56-67.

[22] Mulabisana, J., Cloete, M., Laurie, S. M., Mphela, W. M., Maserumule, M. M., Nhlapo, T., Cochrane, N. M., Oelofse, D., Rey, C. E. (2019): Yield evaluation of multiple and coinfections of begomoviruses and potyviruses on sweet potato varieties under field conditions and confirmation of multiple infection by NGS. - Crop Protection 119: 102-12.

[23] Muthoni, J., Hussein, S., Rob, M. (2015): Genotype and environment interaction and stability of potato tuber yield and bacterial wilt resistance in Kenya. - American Journal of Potato Research 92: 367-78.

[24] Naumann, M., Koch, M., Thiel, H., Gransee, A., Pawelzik, E. (2020): The importance of nutrient management for potato production part ii: plant nutrition and tuber quality. - Potato Research 63: 121-37.

[25] Palta, J. P. (2010): Improving potato tuber quality and production by targeted calcium nutrition: the discovery of tuber roots leading to a new concept in potato nutrition. - Potato 


$$
-762 \text { - }
$$

Research 53: 267-75.

[26] Panique, E., Kelling, K. A., Schulte, E. E., Hero, D. E., Stevenson, W. R., James, R. V. (1997): Potassium rate and source effects on potato yield, quality, and disease interaction. - American Potato Journal 74: 379-98.

[27] Petropoulos, S. A., Fernandes, Â., Polyzos, N., Antoniadis, V., Barros, L., Ferreira, C. F. R. I. (2020): The impact of fertilization regime on the crop performance and chemical composition of potato (Solanum Tuberosum L.). - Cultivated in Central Greece. Agronomy 10: 474.

[28] Porter, G. A., Bradbury, W. B., Jonathan, A. S., Geraldine, B. O., Jeffrey, C. M. (1999): Soil management and supplemental irrigation effects on potato: i. soil properties, tuber yield, and quality. - Agronomy Journal 91: 416-25.

[29] Rudack, K., Seddig, S., Sprenger, H., Köhl, R. K., Ordon, U. F. (2017): Drought StressInduced changes in starch yield and physiological traits in potato. - Journal of Agronomy and Crop Science 203: 494-505.

[30] Seibt, K. M., Wenke, T., Wollrab, C., Junghans, H., Muders, K., Dehmer, K. J., Diekmann, K., Schmidt, T. (2012): Development and Application of Sine-Based Markers for Genotyping of Potato Varieties. - Theoretical and Applied Genetics 125: 185-96.

[31] Senbayram, M., Gransee, A., Wahle, V., Thiel, H. (2015): Role of magnesium fertilisers in agriculture: plant-soil continuum. - Crop and Pasture Science 66(12): 1219-29.

[32] Tein, B., Kauer, K., Eremeev, V., Luik, A., Selge, A., Loit, E. (2014): Farming systems affect potato (Solanum tuberosum L.) tuber and soil quality. - Field Crops Research 156: $1-11$.

[33] Tiwari, J. K., Sapna, D., Tanuja, B., Nilofer, A., Rajesh, K. S., Rasna, Z., Vijay, K. D., Swarup, K. C. (2020): Precision phenotyping of contrasting potato (Solanum tuberosum L.) varieties in a novel aeroponics system for improving nitrogen use efficiency: in search of key traits and genes. - Journal of Integrative Agriculture 19: 51-61.

[34] Tyanova, S., Temu, T., Sinitcyn, P., Carlson, A., Hein, M. Y., Geiger, T., Mann, M., Cox, J. (2016): The perseus computational platform for comprehensive analysis of (Prote) omics data. - Nature Methods 13: 731-740.

[35] Van Dingenen, J., Hanzalova, K., Salem, M. A. A., Abel, C., Seibert, T., Giavalisco, P., ahl, V. (2019): Limited nitrogen availability has cultivar-dependent effects on potato tuber yield and tuber quality traits. - Food Chemistry 288: 170-77.

[36] Visscher, A. M., Vanek, S., Meza, K., de Goede, R. G. M., Valverde, A. A., Ccanto, R., Olivera, E., Scurrah, M., Fonte, S. J. (2020): Eucalyptus and alder field margins differ in their impact on ecosystem services and biodiversity within cropping fields of the Peruvian Andes. - Agriculture, Ecosystems \& Environment 303: 107107.

[37] Visvanathan, R., Chathuni, J., Barana, C. J., Ruvini, L. (2016): Health-Beneficial Properties of Potato and Compounds of Interest. - Journal of the Science of Food and Agriculture 96: 4850-60.

[38] Wang, X., Wang, N., Xing, Y., Yun, J., Zhang, H. (2018): Effects of plastic mulching and basal nitrogen application depth on nitrogen use efficiency and yield in maize. - Frontiers in Plant Science 9: 1446.

[39] Wang, H., Xiukang, W., Lifei, B., Ying, W., Junliang, F., Fucang, Z., Xianghao, H., Minghui, C., Wenhui, H., Lifeng, W., Youzhen, X. (2019): Multi-objective optimization of water and fertilizer management for potato production in sandy areas of northern china based on TOPSIS. - Field Crops Research 240: 55-68.

[40] Wang, X., Fan, J., Xing, Y., Xu, G., Wang, H., Deng, J., Wang, Y., Zhang, F., Li, P., Li, Z. (2019): The effects of mulch and nitrogen fertilizer on the soil environment of crop plants. - Adv. Agron. 153: 121-173.

[41] Wang, X., Guo, T., Wang, Y., Xing, Y., Wang, Y., He, X. (2020): Exploring the optimization of water and fertilizer management practices for potato production in the sandy loam soils of northwest china based on PCA. - Agricultural Water Management 237: 106180.

[42] Xing, Y., Niu, X., Wang, N., Jiang, W., Gao, Y., Wang, X. (2020): The Correlation between 


$$
-763 \text { - }
$$

Soil Nutrient and Potato Quality in Loess Plateau of China Based on Plsr. - Sustainability 12: 1588.

[43] Xing, Y., Li, Z., Wang, Y., Wang, Y., Zhang, T., Mi, F., Wang, X. (2021): Exploring optimization of water and nitrogen fertilizer management for potted maize based on PCA. - Pakistan Journal of Botany 53(6): 2067-2083.

[44] Xing, Y., Zhang, T., Jiang, W., Li, P., Shi, P., Xu, G., Cheng, S., Cheng, Y., Zhang, F., Wang, $X$. (2022): Effects of irrigation and fertilization on different potato varieties growth, yield and resources use efficiency in the Northwest China. - Agricultural Water Management 261: 107351.

[45] Yamdeu Galani, J. H., Mankad, P. M., Shah, A. K., Patel, N. J., Acharya, R. R., Talati, J. G. (2017): Effect of storage temperature on vitamin C, total phenolics, uplc phenolic acid profile and antioxidant capacity of eleven potatos (Solanum tuberosum) varieties. Horticultural Plant Journal 3(2): 73-89.

[46] Zaheer, K., Akhtar, M. H. (2016): Potato Production, Usage, and Nutrition-a Review. Critical Reviews in Food Science and Nutrition 56: 711-21.

[47] Zhang, H., Liu, X., Song, B., Nie, B., Wei, Z., Zhao, Z. (2020): Effect of excessive nitrogen on levels of amino acids and sugars, and differential response to post-harvest cold storage in potato (Solanum Tuberosum L.) tubers. - Plant Physiology and Biochemistry 157: 3846.

[48] Zhou, L., Mu, T., Ma, M., Zhang, R., Sun, Q., Xu, Y. (2019): Nutritional evaluation of different cultivars of potatoes (Solanum Tuberosum L.) from china by grey relational analysis (gra) and its application in potato steamed bread making. - Journal of Integrative Agriculture 18: 231-45. 


$$
-764 \text { - }
$$

\section{APPENDIX}

Supplementary Table S1. Mean TY (potato tuber yield), DMA (dry matter accumulation), SC (Starch content), PC (protein content), RS (reducing sugar), TSS (total soluble sugar), VC (vitamin $C$ ), and BI (browning intensity)

\begin{tabular}{c|c|c|c|c|c|c|c|c}
\hline Item & TY & DMA & SC & PC & RS & TSS & VC & BI \\
\hline T1 & 0.84 & 1.1505 & 11.45 & 2.08 & 0.28 & 2.71 & 16.333 & 4.4547 \\
T2 & 1.45 & 1.097 & 8.72 & 1.61 & 0.38 & 1.92 & 13.5 & 5.7287 \\
T3 & 0.91 & 1.14 & 8.4 & 1.99 & 0.88 & 1.92 & 13.625 & 11.372 \\
T4 & 0.92 & 1.075 & 11.64 & 1.38 & 0.39 & 2.13 & 12.667 & 10.021 \\
T5 & 1.16 & 1.22 & 11.19 & 1.6 & 0.26 & 1.39 & 12.208 & 8.9073 \\
T6 & 0.75 & 1.1565 & 11.2 & 1.69 & 0.31 & 1.72 & 11.792 & 7.96 \\
T7 & 1.12 & 0.935 & 10.8 & 1.11 & 0.77 & 1.91 & 11.833 & 8.8993 \\
T8 & 0.64 & 1.058 & 10.53 & 1.16 & 0.63 & 1.25 & 12.417 & 5.058 \\
T9 & 0.66 & 1.0955 & 8.79 & 1.31 & 0.38 & 2.55 & 11.167 & 9.82 \\
T10 & 0.48 & 1.1105 & 6.99 & 0.92 & 0.55 & 2.54 & 12.042 & 4.6733 \\
T11 & 0.99 & 1.1635 & 10.37 & 1.45 & 0.44 & 2.06 & 9.7083 & 14.92 \\
T12 & 0.77 & 1.0705 & 10.39 & 1.64 & 0.36 & 2.23 & 9.5833 & 6.98 \\
T13 & 0.67 & 1.0435 & 10.06 & 2.34 & 0.82 & 3.42 & 6.9583 & 4.8633 \\
T14 & 1 & 1.237 & 10.67 & 2.9 & 0.3 & 1.81 & 8.625 & 10.677 \\
T15 & 0.41 & 1.2115 & 10.57 & 3.08 & 0.38 & 2.11 & 8.5833 & 8.69 \\
\hline
\end{tabular}

Supplementary Table S2. The standardized values of TY (potato tuber yield), DMA (dry matter accumulation), SC (Starch content), PC (protein content), RS (reducing sugar), TSS (total soluble sugar), VC (vitamin C), and BI (browning intensity)

\begin{tabular}{c|c|c|c|c|c|c|c|c}
\hline Item & TY & DMA & SC & PC & RS & TSS & VC & BI \\
\hline T1 & -0.042 & 0.419 & 1.014 & 0.524 & -0.951 & 1.108 & 2.071 & -1.261 \\
T2 & 2.197 & -0.263 & -1.064 & -0.224 & -0.464 & -0.354 & 0.881 & -0.832 \\
T3 & 0.215 & 0.286 & -1.308 & 0.381 & 1.970 & -0.354 & 0.934 & 1.067 \\
T4 & 0.252 & -0.543 & 1.159 & -0.590 & -0.415 & 0.035 & 0.531 & 0.612 \\
T5 & 1.133 & 1.305 & 0.816 & -0.240 & -1.048 & -1.336 & 0.338 & 0.237 \\
T6 & -0.372 & 0.496 & 0.824 & -0.097 & -0.805 & -0.725 & 0.163 & -0.081 \\
T7 & 0.986 & -2.328 & 0.519 & -1.019 & 1.435 & -0.373 & 0.181 & 0.235 \\
T8 & -0.776 & -0.760 & 0.314 & -0.940 & 0.753 & -1.595 & 0.426 & -1.058 \\
T9 & -0.702 & -0.282 & -1.011 & -0.701 & -0.464 & 0.812 & -0.099 & 0.545 \\
T10 & -1.363 & -0.091 & -2.382 & -1.322 & 0.364 & 0.794 & 0.268 & -1.187 \\
T11 & 0.509 & 0.585 & 0.192 & -0.478 & -0.172 & -0.095 & -0.712 & 2.261 \\
T12 & -0.299 & -0.600 & 0.207 & -0.176 & -0.562 & 0.220 & -0.764 & -0.411 \\
T13 & -0.666 & -0.945 & -0.044 & 0.938 & 1.678 & 2.423 & -1.867 & -1.123 \\
T14 & 0.546 & 1.522 & 0.420 & 1.829 & -0.854 & -0.558 & -1.167 & 0.833 \\
T15 & -1.620 & 1.197 & 0.344 & 2.115 & -0.464 & -0.002 & -1.184 & 0.164 \\
\hline
\end{tabular}




$$
-765 \text { - }
$$

Supplementary Table S3. The standardized values of TY (potato tuber yield), DMA (dry matter accumulation), SC (Starch content), PC (protein content), RS (reducing sugar), TSS (total soluble sugar), $V C$ (vitamin $C$ ), and BI (browning intensity)

\begin{tabular}{c|cccccccc}
\hline Items & TY & DMA & SC & PC & RS & TSS & VC & BI \\
\hline TY & 1 & -0.055 & 0.158 & -0.146 & -0.117 & -0.353 & 0.318 & 0.243 \\
DMA & -0.055 & 1 & 0.094 & 0.572 & -0.591 & -0.23 & -0.071 & 0.303 \\
SC & 0.158 & 0.094 & 1 & 0.262 & -0.372 & -0.243 & -0.032 & 0.137 \\
PC & -0.146 & 0.572 & 0.262 & 1 & -0.156 & 0.172 & -0.425 & 0.091 \\
RS & -0.117 & -0.591 & -0.372 & -0.156 & 1 & 0.214 & -0.111 & -0.052 \\
TSS & -0.353 & -0.23 & -0.243 & 0.172 & 0.214 & 1 & -0.249 & -0.294 \\
VC & 0.318 & -0.071 & -0.032 & -0.425 & -0.111 & -0.249 & 1 & -0.222 \\
BI & 0.243 & 0.303 & 0.137 & 0.091 & -0.052 & -0.294 & -0.222 & 1 \\
\hline
\end{tabular}

Supplementary Table S4. Total variance explained of the contribution rate and accumulative of contribution rate with eigenvalues was calculated by principal component analysis

\begin{tabular}{|c|c|c|c|c|c|c|c|c|c|}
\hline \multirow{2}{*}{ Component } & \multicolumn{3}{|c|}{ Initial Eigenvalues } & \multicolumn{3}{|c|}{$\begin{array}{c}\text { Extraction Sums of Squared } \\
\text { Loadings }\end{array}$} & \multicolumn{3}{|c|}{$\begin{array}{c}\text { Rotation Sums of Squared } \\
\text { Loadings }\end{array}$} \\
\hline & Total & $\begin{array}{c}\% \text { of } \\
\text { Variance } \\
\end{array}$ & $\begin{array}{c}\text { Cumulative } \\
\% \\
\end{array}$ & Total & $\begin{array}{c}\% \text { of } \\
\text { Variance }\end{array}$ & $\begin{array}{c}\text { Cumulative } \\
\%\end{array}$ & Total & $\begin{array}{c}\% \text { of } \\
\text { Variance }\end{array}$ & $\begin{array}{c}\text { Cumulative } \\
\% \\
\end{array}$ \\
\hline 1 & 2.273 & 28.418 & 28.418 & 2.273 & 28.418 & 28.418 & 2.081 & 26.012 & 26.012 \\
\hline 2 & 1.901 & 23.762 & 52.180 & 1.901 & 23.762 & 52.180 & 1.801 & 22.513 & 48.525 \\
\hline 3 & 1.163 & 14.539 & 66.719 & 1.163 & 14.539 & 66.719 & 1.456 & 18.194 & 66.719 \\
\hline 4 & .928 & 11.600 & 78.319 & & & & & & \\
\hline 5 & .676 & 8.446 & 86.765 & & & & & & \\
\hline 6 & .546 & 6.821 & 93.586 & & & & & & \\
\hline 7 & .424 & 5.295 & 98.881 & & & & & & \\
\hline 8 & .090 & 1.119 & 100.000 & & & & & & \\
\hline
\end{tabular}

Supplementary Table S5. The three components are extracted matrix by principal component analysis of all parameters

\begin{tabular}{c|c|c|c}
\hline \multirow{2}{*}{ Items } & \multicolumn{3}{|c}{ Component } \\
\cline { 2 - 4 } & $\mathbf{1}$ & $\mathbf{2}$ & $\mathbf{3}$ \\
\hline TY & 0.219 & 0.685 & 0.248 \\
DMA & 0.813 & -0.221 & -0.184 \\
SC & 0.549 & 0.119 & -0.066 \\
PC & 0.557 & -0.648 & -0.02 \\
RS & -0.709 & -0.126 & 0.506 \\
TSS & -0.444 & -0.63 & -0.177 \\
VC & -0.126 & 0.726 & -0.464 \\
BI & 0.487 & 0.098 & 0.749 \\
TY & 0.219 & 0.685 & 0.248 \\
\hline
\end{tabular}

Extraction Method: Principal Component Analysis. a. 3 components extracted. Note: TY, potato tuber yield; DMA, dry matter accumulation; SC, Starch content; PC, protein content; RS, reducing sugar; TSS, total soluble sugar; VC, vitamin C; BI, browning intensity 


$$
\text { - } 766 \text { - }
$$

Supplementary Table S6. The three component scores are extracted coefficient matrix by principal component analysis of all parameters

\begin{tabular}{c|c|c|c}
\hline \multirow{2}{*}{ Items } & \multicolumn{3}{|c}{ Component } \\
\cline { 2 - 4 } & $\mathbf{1}$ & $\mathbf{2}$ & $\mathbf{3}$ \\
\hline TY & -0.052 & 0.426 & 0.007 \\
DMA & 0.404 & -0.048 & 0.034 \\
SC & 0.232 & 0.108 & -0.012 \\
PC & 0.277 & -0.211 & 0.235 \\
RS & -0.449 & 0.031 & 0.297 \\
TSS & -0.066 & -0.408 & 0 \\
VC & 0.057 & 0.126 & -0.537 \\
BI & -0.077 & 0.396 & 0.548 \\
\hline
\end{tabular}

Note: TY, potato tuber yield; DMA, dry matter accumulation; SC, Starch content; PC, protein content; RS, reducing sugar; TSS, total soluble sugar; VC, vitamin C; BI, browning intensity

Supplementary Table S7. The first component scores are calculated by extracted coefficient matrix one by principal component analysis

\begin{tabular}{c|c|c|c|c|c|c|c|c|c}
\hline Item & TY & DMA & SC & PC & RS & TSS & VC & BI & Sum \\
\hline T1 & 0.002 & 0.169 & 0.235 & 0.145 & 0.427 & -0.073 & 0.118 & 0.097 & 1.121 \\
T2 & -0.114 & -0.106 & -0.247 & -0.062 & 0.208 & 0.023 & 0.050 & 0.064 & -0.183 \\
T3 & -0.011 & 0.115 & -0.303 & 0.105 & -0.885 & 0.023 & 0.053 & -0.082 & -0.984 \\
T4 & -0.013 & -0.219 & 0.269 & -0.163 & 0.187 & -0.002 & 0.030 & -0.047 & 0.040 \\
T5 & -0.059 & 0.527 & 0.189 & -0.066 & 0.471 & 0.088 & 0.019 & -0.018 & 1.151 \\
T6 & 0.019 & 0.200 & 0.191 & -0.027 & 0.361 & 0.048 & 0.009 & 0.006 & 0.809 \\
T7 & -0.051 & -0.940 & 0.120 & -0.282 & -0.644 & 0.025 & 0.010 & -0.018 & -1.781 \\
T8 & 0.040 & -0.307 & 0.073 & -0.260 & -0.338 & 0.105 & 0.024 & 0.081 & -0.581 \\
T9 & 0.037 & -0.114 & -0.235 & -0.194 & 0.208 & -0.054 & -0.006 & -0.042 & -0.399 \\
T10 & 0.071 & -0.037 & -0.553 & -0.366 & -0.163 & -0.052 & 0.015 & 0.091 & -0.993 \\
T11 & -0.026 & 0.236 & 0.045 & -0.133 & 0.077 & 0.006 & -0.041 & -0.174 & -0.009 \\
T12 & 0.016 & -0.243 & 0.048 & -0.049 & 0.252 & -0.015 & -0.044 & 0.032 & -0.002 \\
T13 & 0.035 & -0.382 & -0.010 & 0.260 & -0.753 & -0.160 & -0.106 & 0.086 & -1.031 \\
T14 & -0.028 & 0.615 & 0.098 & 0.507 & 0.383 & 0.037 & -0.067 & -0.064 & 1.480 \\
T15 & 0.084 & 0.484 & 0.080 & 0.586 & 0.208 & 0.000 & -0.068 & -0.013 & 1.362 \\
\hline
\end{tabular}

Supplementary Table S8. The second component scores are calculated by extracted coefficient matrix two by principal component analysis

\begin{tabular}{c|c|c|c|c|c|c|c|c|c}
\hline Item & TY & DMA & SC & PC & RS & TSS & VC & BI & Sum \\
\hline T1 & -0.018 & -0.020 & 0.110 & -0.111 & -0.029 & -0.452 & 0.261 & -0.499 & -0.759 \\
T2 & 0.936 & 0.013 & -0.115 & 0.047 & -0.014 & 0.145 & 0.111 & -0.330 & 0.793 \\
T3 & 0.092 & -0.014 & -0.141 & -0.080 & 0.061 & 0.145 & 0.118 & 0.422 & 0.602 \\
T4 & 0.107 & 0.026 & 0.125 & 0.124 & -0.013 & -0.014 & 0.067 & 0.242 & 0.665 \\
T5 & 0.483 & -0.063 & 0.088 & 0.051 & -0.033 & 0.545 & 0.043 & 0.094 & 1.208 \\
T6 & -0.158 & -0.024 & 0.089 & 0.020 & -0.025 & 0.296 & 0.021 & -0.032 & 0.186 \\
T7 & 0.420 & 0.112 & 0.056 & 0.215 & 0.044 & 0.152 & 0.023 & 0.093 & 1.115 \\
T8 & -0.330 & 0.036 & 0.034 & 0.198 & 0.023 & 0.651 & 0.054 & -0.419 & 0.247 \\
T9 & -0.299 & 0.014 & -0.109 & 0.148 & -0.014 & -0.331 & -0.012 & 0.216 & -0.390 \\
T10 & -0.581 & 0.004 & -0.257 & 0.279 & 0.011 & -0.324 & 0.034 & -0.470 & -1.304 \\
T11 & 0.217 & -0.028 & 0.021 & 0.101 & -0.005 & 0.039 & -0.090 & 0.895 & 1.149 \\
T12 & -0.127 & 0.029 & 0.022 & 0.037 & -0.017 & -0.090 & -0.096 & -0.163 & -0.405 \\
T13 & -0.284 & 0.045 & -0.005 & -0.198 & 0.052 & -0.989 & -0.235 & -0.445 & -2.057 \\
T14 & 0.232 & -0.073 & 0.045 & -0.386 & -0.026 & 0.228 & -0.147 & 0.330 & 0.203 \\
T15 & -0.690 & -0.057 & 0.037 & -0.446 & -0.014 & 0.001 & -0.149 & 0.065 & -1.254 \\
\hline
\end{tabular}




$$
-767 \text { - }
$$

Supplementary Table S9. The third component scores are calculated by extracted coefficient matrix three by principal component analysis

\begin{tabular}{c|c|c|c|c|c|c|c|c|c}
\hline Item & TY & DMA & SC & PC & RS & TSS & VC & BI & Sum \\
\hline T1 & -0.018 & -0.020 & 0.110 & -0.111 & -0.029 & -0.452 & 0.261 & -0.499 & -0.759 \\
T2 & 0.936 & 0.013 & -0.115 & 0.047 & -0.014 & 0.145 & 0.111 & -0.330 & 0.793 \\
T3 & 0.092 & -0.014 & -0.141 & -0.080 & 0.061 & 0.145 & 0.118 & 0.422 & 0.602 \\
T4 & 0.107 & 0.026 & 0.125 & 0.124 & -0.013 & -0.014 & 0.067 & 0.242 & 0.665 \\
T5 & 0.483 & -0.063 & 0.088 & 0.051 & -0.033 & 0.545 & 0.043 & 0.094 & 1.208 \\
T6 & -0.158 & -0.024 & 0.089 & 0.020 & -0.025 & 0.296 & 0.021 & -0.032 & 0.186 \\
T7 & 0.420 & 0.112 & 0.056 & 0.215 & 0.044 & 0.152 & 0.023 & 0.093 & 1.115 \\
T8 & -0.330 & 0.036 & 0.034 & 0.198 & 0.023 & 0.651 & 0.054 & -0.419 & 0.247 \\
T9 & -0.299 & 0.014 & -0.109 & 0.148 & -0.014 & -0.331 & -0.012 & 0.216 & -0.390 \\
T10 & -0.581 & 0.004 & -0.257 & 0.279 & 0.011 & -0.324 & 0.034 & -0.470 & -1.304 \\
T11 & 0.217 & -0.028 & 0.021 & 0.101 & -0.005 & 0.039 & -0.090 & 0.895 & 1.149 \\
T12 & -0.127 & 0.029 & 0.022 & 0.037 & -0.017 & -0.090 & -0.096 & -0.163 & -0.405 \\
T13 & -0.284 & 0.045 & -0.005 & -0.198 & 0.052 & -0.989 & -0.235 & -0.445 & -2.057 \\
T14 & 0.232 & -0.073 & 0.045 & -0.386 & -0.026 & 0.228 & -0.147 & 0.330 & 0.203 \\
T15 & -0.690 & -0.057 & 0.037 & -0.446 & -0.014 & 0.001 & -0.149 & 0.065 & -1.254 \\
\hline
\end{tabular}
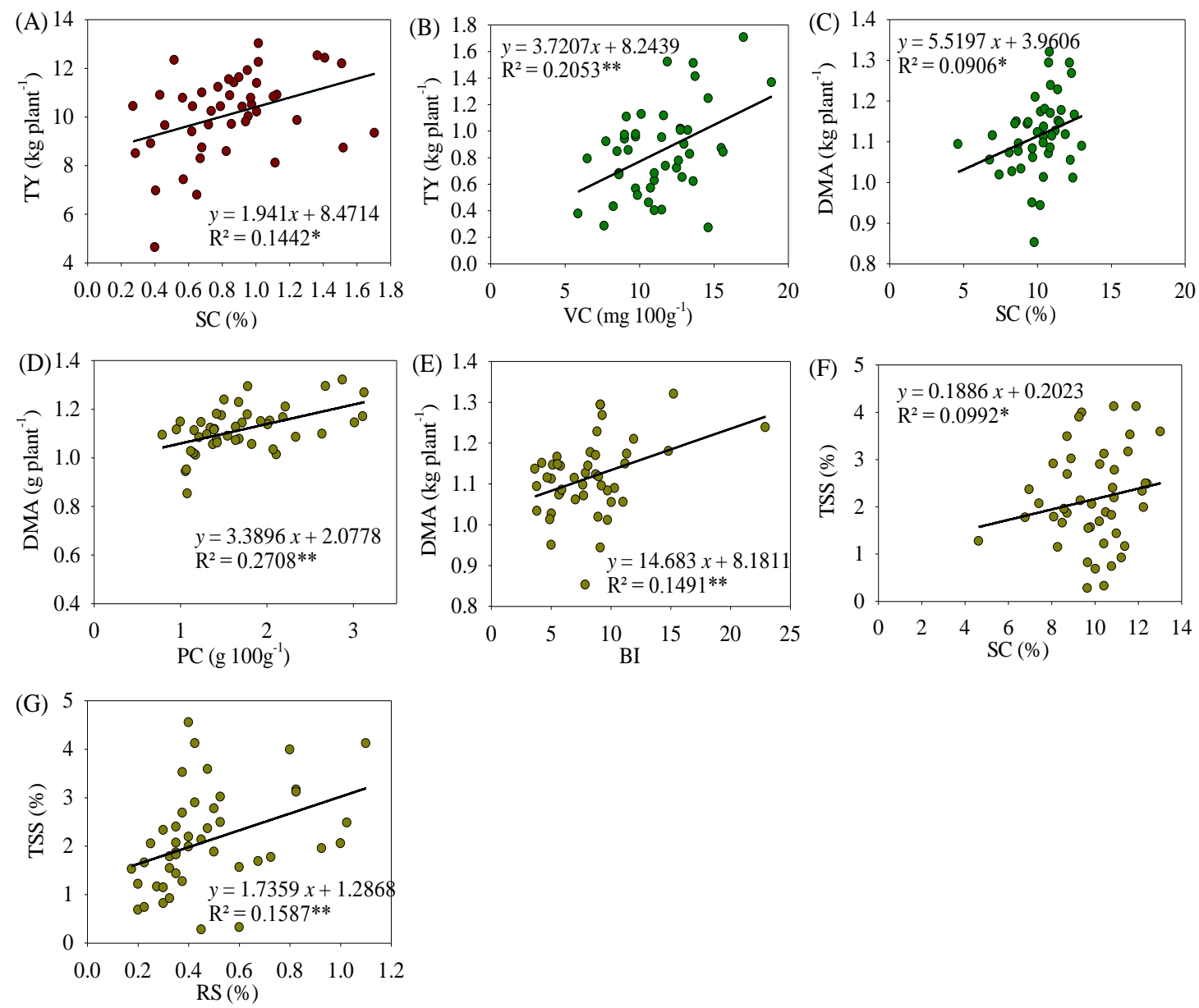

Supplementary Figure S1. The linear relationship between potato tuber quality. Note: TY, potato tuber yield; DMA, dry matter accumulation; SC, Starch content; PC, protein content; $R S$, reducing sugar; TSS, total soluble sugar; VC, vitamin C; BI, browning intensity 

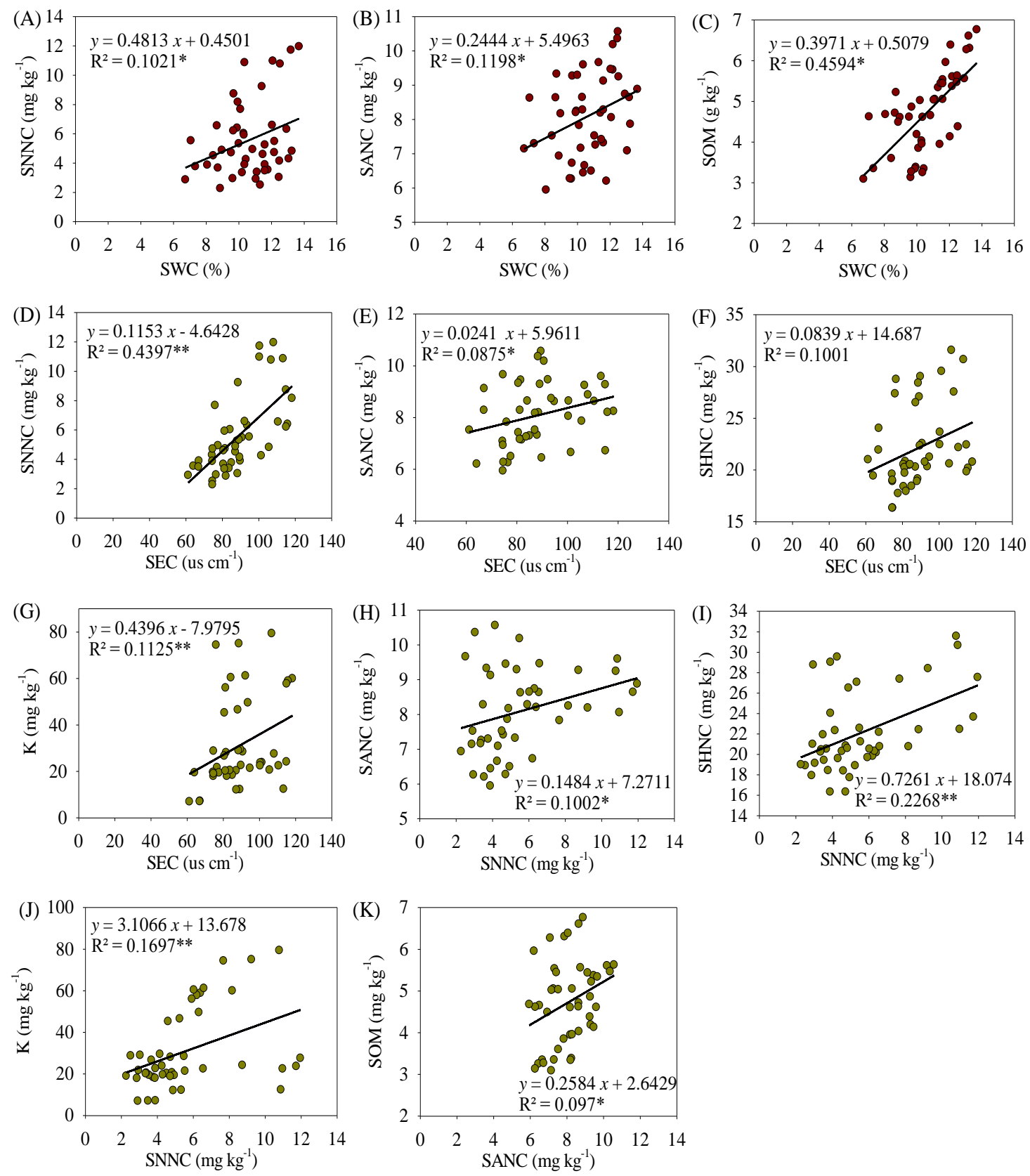

Supplementary Figure $\mathbf{S 2}$. The linear relationship between soil indexes. Note: SWC, soil water content; $p H$, soil $p H ; S E C$, soil electric conductivity; SNNC, soil nitrate-N content; SANC, soil ammonium N content; SHNC, soil alkali-hydrolyzable N content. SOM, soil organic matter; $P$, soil available phosphorus; $K$, soil available potassium 


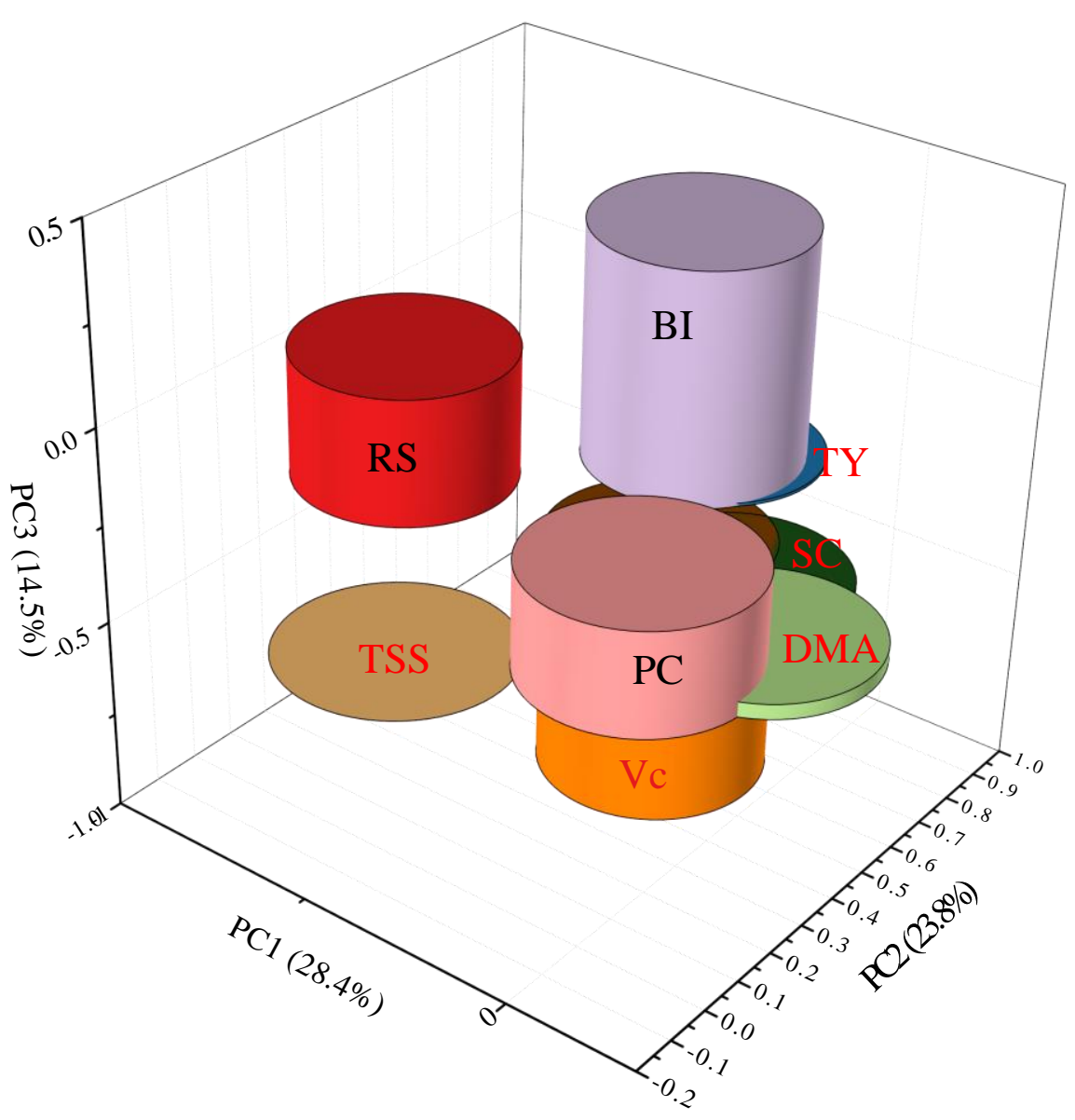

Supplementary Figure S3. Principal component analysis of potato tuber yield and tuber quality. Note: TY, potato tuber yield; DMA, dry matter accumulation; SC, Starch content; PC, protein content; $R S$, reducing sugar; TSS, total soluble sugar; VC, vitamin $C ; B I$, browning intensity 